\title{
BMP signaling in mesenchymal stem cell differentiation and bone formation*
}

\author{
Maureen Beederman ${ }^{1 \#}$, Joseph D. Lamplot ${ }^{1 \#}$, Guoxin Nan ${ }^{1,2}$, Jinhua Wang ${ }^{1,3}$, Xing Liu ${ }^{1,2}$, \\ Liangjun Yin ${ }^{1,3}$, Ruidong $\mathrm{Li}^{1,3}$, Wei Shui ${ }^{1,3}$, Hongyu Zhang ${ }^{1,3}$, Stephanie H. Kim ${ }^{1}$, Wenwen Zhang ${ }^{1,3}$, \\ Jiye Zhang ${ }^{1,3}$, Yuhan Kong ${ }^{1,3}$, Sahitya Denduluri ${ }^{1}$, Mary Rose Rogers ${ }^{1}$, Abdullah Pratt ${ }^{1}$, \\ Rex C. Haydon ${ }^{1}$, Hue H. Luu ${ }^{1}$, Jovito Angeles ${ }^{1}$, Lewis L. Shi ${ }^{1}$, Tong-Chuan He ${ }^{1,2,3 \dagger}$ \\ ${ }^{1}$ Molecular Oncology Laboratory, Department of Orthopaedic Surgery, The University of Chicago Medical Center, Chicago, USA
${ }^{2}$ Stem Cell Biology and Therapy Laboratory of the Key Laboratory for Pediatrics Co-Designated by Chinese Ministry of Education,
The Children's Hospital of Chongqing Medical University, Chongqing, China
${ }^{3}$ The Affiliated Hospitals and the Key Laboratory of Diagnostic Medicine Designated by the Chinese Ministry of Education,
Chongqing Medical University, Chongqing, China \\ Email:
}

Received 5 April 2013; revised 8 May 2013; accepted 20 May 2013

Copyright (C) 2013 Maureen Beederman et al. This is an open access article distributed under the Creative Commons Attribution License, which permits unrestricted use, distribution, and reproduction in any medium, provided the original work is properly cited.

\section{ABSTRACT}

Bone morphogenetic proteins (BMPs) are members of the TGF- $\beta$ superfamily and have diverse functions during development and organogenesis. BMPs play a major role in skeletal development and bone formation, and disruptions in BMP signaling cause a variety of skeletal and extraskeletal anomalies. Several knockout models have provided insight into the mechanisms responsible for these phenotypes. Proper bone formation requires the differentiation of osteoblasts from mesenchymal stem cell (MSC) precursors, a process mediated in part by BMP signaling. Multiple BMPs, including BMP2, BMP6, BMP7 and BMP9, promote osteoblastic differentiation of MSCs both in vitro and in vivo. BMP9 is one of the most osteogenic BMPs, yet it is a poorly characterized member of the BMP family. Several studies demonstrate that the mechanisms controlling BMP9-mediated osteogenesis differ from other osteogenic BMPs, but little is known about these specific mechanisms. Several pathways critical to BMP9-mediated osteogenesis are also important in the differentiation of other cell lineages, including adipocytes and chondrocytes. BMP9 has also demonstrated translational promise in spinal fusion and bone fracture repair. This review will summarize our current knowledge of BMP-mediated osteogenesis, with a focus on BMP9, by presenting recently com-

\footnotetext{
The authors declare no conflicts of interest.

\#These authors contributed equally to the work.

${ }^{\dagger}$ Corresponding author.
}

pleted work which may help us to further elucidate these pathways.

Keywords: BMP; BMP9; Bone Regeneration; IGF; Osteogenesis; TGF- $\beta$; Wnt; Signal Transduction; Mesenchymal Stem Cells; MSCs

\section{INTRODUCTION}

Bone morphogenetic proteins (BMPs) are members of the transforming group factor-beta (TGF- $\beta$ ) superfamily. This group of homologous signaling proteins has a diverse number of functions and plays an important role in embryogenesis, organogenesis, cell proliferation and stem cell differentiation [1-5]. For example, BMP7 is involved in proper kidney, eye, and limb development; BMPs 4, 7 and 15 are important for proper reproductive tissue development; BMPs 2, 3 and 7 contribute to cartilage regeneration; and BMPs 12 and 13 are required for normal tendon healing [6-12]. BMPs also play a major role in skeletal development, bone formation and mesenchymal stem cell (MSC) differentiation [13,14].

MSCs are adult stem cells found in the bone marrow and like all other types of stem cells. They have the unique ability to self-renew and to differentiate into various mesodermal cell lineages, osteoblastic, chondrocytic, myocytic and adipocytic, as well as non-mesodermal tissues, such as cardiac muscle and skin [11,13,15-18] (Figure 1). The differentiation of these multipotent stem cells towards an osteoblastic fate depends on numerous signaling pathways, including BMP transduction. The osteoinductive 


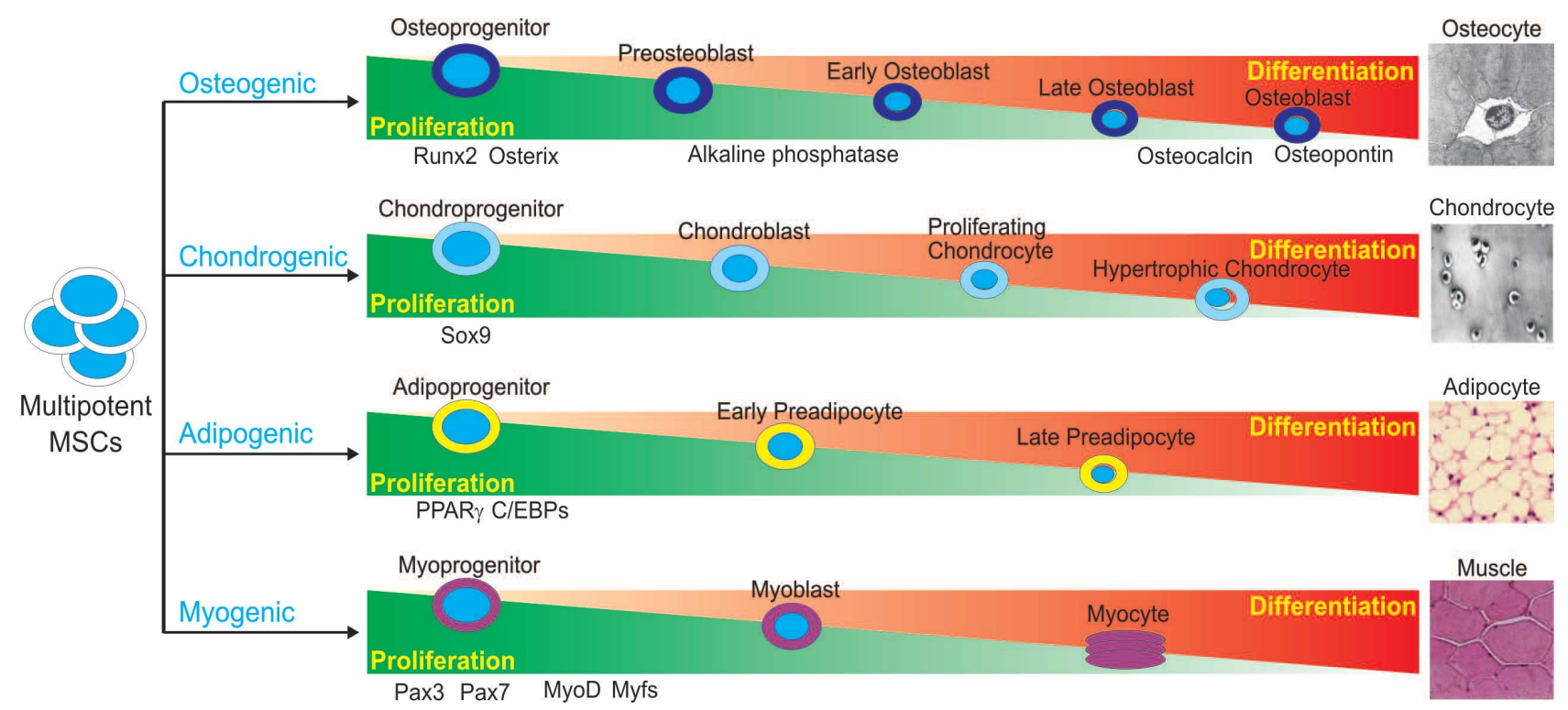

Figure 1. Schematic representation of lineage-specific differentiation of mesenchymal stem cells (MSCs). MSCs are pluripotent progenitor cells with the ability to differentiate along multiple lineages, including osteogenic, chondrogenic, adipogenic and myogenic lineages. Differentiation of MSCs along these unique lineages is an exquisitely coordinated process with critical regulators responsible for each lineage. Regulators and indicators of lineage-specific differentiation are depicted.

ability of BMPs was discovered when it was found that demineralized bone could induce de novo bone formation and that BMPs were responsible for this observed osteogenesis $[19,20]$. Disruptions in BMP signaling have subsequently been shown to result in a variety of skeletal and extraskeletal anomalies [21,22]. At least 15 different BMPs have been identified in humans to date.

BMP9, also known as growth differentiation factor 2 or GDF-2, is a relatively poorly characterized member of the BMP family first isolated from fetal mouse liver cDNA libraries. BMP9 is expressed at high levels within the developing mouse liver and acts to stimulate hepatocyte proliferation [23]. It also acts to induce and maintain the cholinergic phenotype within basal forebrain neurons, inhibit hepatic glucose production, inhibit enzymes of lipid metabolism, maintain metabolic homeostasis of iron and synergize in the generation of hematopoietic progenitor cells [24-26].

BMP9 is among the most osteogenic BMPs and promotes the osteoblastic differentiation of mesenchymal stem cells (MSCs) both in vitro and in vivo [11,13,27-30]. We have demonstrated that BMP9 regulates a distinct set of downstream targets likely playing a role in osteoinduction, and these targets will be discussed later in this review [11,27-30]. While BMP9 has been demonstrated as one of the most osteogenic BMPs, little is known about the detailed mechanisms responsible for its functions. This review aims to summarize our current knowledge of BMP9-mediated osteogenesis, which may help us to further elucidate these pathways.

\section{AXIAL SKELETAL DEVELOPMENT AND MSCS}

Mesenchymal stem cells undergo several stages of maturation during their proliferation and differentiation along the osteoblastic lineage. MSCs initially form preosteoblasts, which proliferate near the surface of bone and secrete alkaline phosphatase, an early marker of osteogenesis [11,31-33]. Preosteoblasts further mature into osteoblasts, which are involved in initial extracellular matrix maturation and mineralization. Osteoblasts ultimately form osteocytes, which are mature, terminally differentiated cells embedded in an extracellular matrix responsible for mechanical support and regulating the mineralization of bone $[34,35]$. These stages of osteogenic proliferation and differentiation are characterized by the expression of various markers, including cell-cycle associated genes during the proliferative phase, the early osteoblastic marker alkaline phosphatase and late markers osteocalcin and osteopontin [36].

From MSCs, bone can form in one of two ways, either by endochondral or intramembranous ossification [36]. The majority of bones in the human skeleton are formed via endochondral ossification, whereby MSCs first differentiate into chondrocytes and secrete a cartilaginous matrix. This matrix subsequently undergoes osteoblast-facilitated ossification to form bone [37-39]. Flat bones, which mainly comprise the axial skeleton, are formed by intramembranous ossification and do not have a cartilaginous precursor scaffold. Instead, MSCs differentiate directly into osteoblasts, which secrete an osteoid matrix 
to form bone $[37,38]$. The bone formed by both of these processes is a highly vascularized tissue which undergoes constant remodeling, necessitating a balance between hematopoietic-derived osteoclasts, which break down bone, and mesenchymal-derived osteoblasts, which rebuild bone $[36,40,41]$. Thus, bone maintenance and remodeling depends, in part, on the proper formation of osteoblasts from MSCs, a highly regulated and complex process in which the BMP signaling pathway plays a critical role.

\section{BMP KNOCKOUT PHENOTYPES}

The BMP signaling pathway plays many crucial roles in bone formation and is involved in multiple stages of the developmental process, including osteoblast differentiation, mesoderm patterning, bone formation, and craniofacial and limb development. Knockout of specific BMPs or mediators of BMP signal transduction often leads to phenotypes which demonstrate the critical importance of BMP signaling in skeletal development.

BMP signaling is required for the differentiation of multipotent mesenchymal cells into osteochondroprogenitor cells, which are capable of forming both chondrocytes and osteoblasts. BMP signal transduction is also necessary for the proper functioning of differentiated osteoblasts, enabling them to appropriately secrete the matrix upon which bone formation occurs [31]. This is especially important during development, when the axial skeleton forms from cellular condensations of mesenchymal cells, which proceed to form bone via the previously described process of endochondral ossification. The first genetic evidence that BMPs have a role in bone morphogenesis was natural loss-of-function mutations of BMP5, resulting in short ear phenotype and brachypodism [22,42]. Subsequent studies have supported the crucial role of BMP signaling in both cartilage and bone formation during endochondral ossification [43-46].

To investigate the functions of BMP2 and BMP4 in the growth plate, chondrocyte-specific BMP2 and BMP4 conditional knockout mice and BMP2/BMP4 conditional double knockout mice were developed [47]. Deletion of BMP2 and BMP4 or BMP2 alone resulted in a severe chondrodysplastic phenotype, while deletion of BMP4 alone had minor effects on cartilage development. Double knockout and BMP2 knockouts demonstrated disorganization of chondrocytes within the growth plate, decreased cell proliferation, poor differentiation and increased apoptosis. BMP2 up-regulated protein expression of the essential osteogenic regulator Runx2. These findings demonstrate that BMP2, but not BMP4, is critical in chondrocytic differentiation and hypertrophy within the growth plate during endochondral bone formation.

BMPs have been shown to regulate endochondral ossification by promoting chondrocyte proliferation and in- ducing chondrocyte hypertrophy [48-50]. Loss of the inhibitory Smad, Smad6, in mice causes defects in axial and appendicular skeletal development [48]. Smad6 double knockouts demonstrate posterior transformation of the cervical vertebrae, ossification centers within lumbar vertebrae and incomplete sternal band fusion. These mice feature delayed hypertrophic differentiation and mineralization during gestation. However, by late gestation, the hypertrophic zone within the growth plate demonstrated an increased pool of proliferating, hypertrophic chondrocytes likely caused by increased BMP responsiveness in the Smad6 knockout mutants. Smad6 thus appears to be necessary to limit BMP signaling during endochondral bone formation.

Smad1 is a critical immediate downstream mediator of BMP receptor transduction [51,52]. Chondrocyte-specific and osteoblast-specific Smad1 conditional knockout mice were bred to assess postnatal bone formation [51]. Chondrocyte-specific deletion of the Smad1 gene resulted in delayed calvarial bone development. Osteoblast-specific deletion resulted in partial inhibition of BMP signaling and an osteopenic phenotype, with impaired osteoblastic proliferation and differentiation. These findings demonstrate the critical role of Smad1 and BMP signal transduction in postnatal bone formation.

Several studies have also investigated mediators and inhibitors of BMP signal transduction. Noggin is a wellestablished antagonist of BMPs, and overexpression of noggin results in osteopenia [53-56]. Other studies have also shown that bone and skeletal development are decreased when BMP antagonists are overexpressed in osteoblasts $[45,57]$. While complete inactivation of noggin results in death in utero, noggin conditional knockout mice demonstrate decreased weight, shortened femoral length and osteopenia [53]. Although bone formation was found to be increased in 3-month-old mice, adult female mice did not exhibit increased bone formation or remodeling. Noggin-deficient mice also exhibit enlarged growth plates and joint fusions $[48,58]$. These findings indicate that either BMP excess can have a detrimental effect on bone or that noggin has BMP-independent roles in skeletal homeostasis.

In mice with conditional knockout of BMP receptor type IA (BMPRIA), an unexpected increase in bone mass was observed in mouse embryos, neonates and adults [59-61]. Adult bone demonstrated severely decreased resorption due to reduced RANKL-OPG-induced osteoclastogenesis [53]. Expression levels of both bone formation and resorption makers were decreased. In another study, mice with osteoblasts expressing a dominantnegative, non-functional BMP receptor (BMPRIB) exhibited a decrease in bone mineral density, bone volume, and bone formation [62]. Thus, BMP signaling is important both for the initial formation of chondrocytes and 
cartilage, as well as the subsequent formation of bone. These findings demonstrate the importance of BMP signaling in regulating the balance between bone formation and resorption.

Unlike the axial skeleton, which forms from cellular condensations of mesenchymal cells, the craniofacial skeleton and its associated cartilaginous elements are formed from the neural crest. This group of pluripotent cells forms in the dorsal neural tube and subsequently migrates to various areas of the developing embryo, including the skull, differentiating into bone, cartilage, and connective tissue of the head and neck. BMP signaling has been found to play a role in proper neural crest cell formation, migration, and differentiation, with BMP2, 4, and 7 specifically expressed during craniofacial skeletal development $[63,64]$. The importance of BMP signaling in craniofacial development is highlighted by multiple studies [65,66]. In one study, when Alk2, a type I BMP receptor, was conditionally deleted from a murine neural crest population, subsequent craniofacial malformations occurred, including cleft palate, hypotrophic mandible, and reduced ossification of the frontal bone [67].

BMPs are also expressed in the developing limb bud, where they play a role in proper limb formation and contribute to limb patterning along three different axes: anterior-posterior, dorsal-ventral, and proximal-distal. The apical ectodermal ridge is a structure located at the distal ectodermal tip of the limb bud and is especially important for proximal-distal limb patterning. It has been shown that BMP2, 4, and 7 are expressed in the AER, as well as in underlying mesenchymal cells, where these signaling cascades are likely involved in proper limb development $[2,22]$. Since BMP2 and BMP4 are embryonic lethal, conditional knockouts were created to remove BMP2 and BMP4 from the limb bud mesenchyme [68]. A threshold level of BMP signaling was found to be required for the onset of chondrogenesis, and chondrogenic condensations were not formed in limbs deficient in both BMP2 and BMP4. When condensations did form, however, chondrogenic differentiation proceeded normally in the absence of BMP2 and BMP7 or BMP2 and BMP4. Additionally, the combined knockdown of BMP2 and BMP4 from the limb bud resulted in lack of bone marrow cavity formation, as well as inability to form trabecular or cortical bone. Decreased expression of osterix, an osteoblast-specific gene, was also observed, showing that osteoblast differentiation was also decreased in this knockout model [68]. These findings demonstrate the importance of BMP2 and BMP4 in proper limb formation.

Other BMP knockout models also highlight the importance of this signaling cascade in proper bone and skeletal development. BMP7 mutants have multiple skeletal defects, as well as kidney and eye defects $[69,70]$. However, BMP6 mutations only result in minor sternal defects [71]. BMP11 mutations result in defects of anterior-posterior axial skeletal patterning [72]. Meanwhile, BMP3 inactivation results in increased bone density [73]. Although BMP2 and -4 mutant embryos die in utero before limb phenotypes can be determined, deletion of BMP7 embryos display polydactyly with incomplete penetrance and otherwise normal limbs [5,69,70,74]. These many studies highlight the critical importance of BMPs and mediators of BMP signal transduction in skeletal development and homeostasis (Table 1).

\section{BMPS AND OSTEOGENESIS}

While the specific molecular mechanisms underlying BMP-mediated osteogenesis are not well-characterized, studies have demonstrated that BMPs play a critical role in osteogenic differentiation; overexpression of osteogenic BMPs with adenoviral, retroviral and recombinant systems have induced bone formation in animal studies [75-95] (Table 2). Exposure of MSCs to osteogenic BMPs results in increased expression of osteoblast-specific markers, including the early osteogenic marker alkaline phosphatase (ALP), the late osteogenic markers osteocalcin and osteopontin, connective tissue growth factor (CTGF), inhibitor of DNA binding (Id) and Cbfa1/ Runx2 [11,18,28-30,96-98].

Among the osteogenic BMPs, BMP2 and BMP7 were the first to be studied in depth. Adenoviral-mediated delivery of BMP2 to MSCs and other nonosteogenic cells increases osteogenic activity in vitro, lending support to the role of BMP2 in osteoblastic differentiation [76,86, 99,100]. C3H10T1/2 cells overexpressing AdBMP2 exhibited increased ALP activity, mineralization and mRNA expression of bone-specific proteins including type I collagen, osteopontin and osteocalcin [86,99]. AdBMP2transfected bone marrow osteoprogenitor cells formed bone when seeded onto biodegradable polymer scaffolds as assessed by increased ALP activity, type I collagen production and mineralization [100]. BMP7 has also demonstrated the ability to induce osteogenesis. AdBMP7transduced C2C12 myoblasts and muscle-derived progenitor cells differentiated into osteoblasts as assessed by ALP activity and matrix mineralization [81]. Furthermore, adipose-derived adult stem cells transduced with AdBMP7 differentiated into osteoblasts, eventually formed bone [101].

Both BMP2 and BMP7 have the ability to induce osteogenesis in vivo. Several studies have shown that MSCs and other progenitor cell types transduced with BMP2 or BMP7 induces bone formation in various animal models [75,76,78,79,81,83-86,88,89,91,99-102]. AdBMP2 injected directly into the thighs of rats led to bone formation at the injection sites as observed with $\mathrm{CT}$, digital radiography and planar radionuclide scintigraphy [102]. When 
Table 1. Examples of BMP-induced osteogenesis in MSCs.

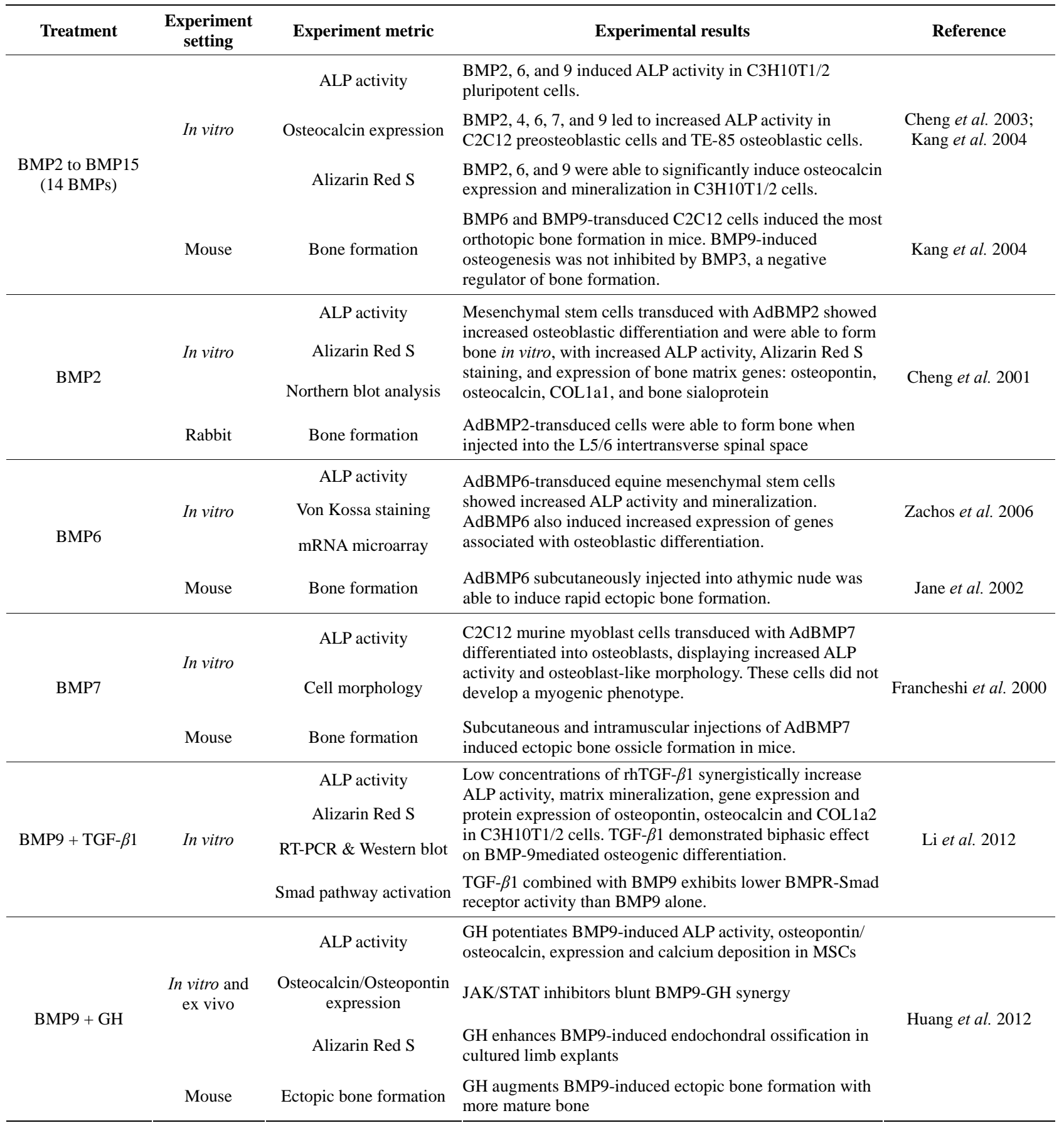

AdBMP7-transduced human and rat fibroblasts were subcutaneously implanted in mice, these normally nonosteogenic cells differentiated into osteoblasts and induced bone formation [83].

Non-adenoviral vectors, including recombinant BMP2 (rhBMP2) and rhBMP7, also induce bone formation [82, 95,103-108]. Treatment of C3H10T1/2 cells with rhBMP2 increased ALP activity [105]. In a canine ulnar segmental defect model, rhBMP7 treatment initiated new bone formation and led to defect repair and complete bony union [103]. rhBMP2 has shown a similar ability to repair bony defects in animal models [73].

The results from these studies demonstrating the osteoinductive properties of BMP2 and BMP7 have increased the clinical utilization of recombinant BMPs. In degenerative lumbar disc disease patients, use of rhBMP2/ collagen within a lumbar spine interbody fusion cage achieved better fusion rates than use of autologous bone 
Table 2. Skeletal phenotypes of several members of the BMP signaling pathway.

\begin{tabular}{|c|c|c|c|}
\hline Deleted gene & Cells affected & Skeletal phenotype & Reference \\
\hline $\begin{array}{c}\text { BMP2; } \\
\mathrm{BMP} 2+4\end{array}$ & Chondrocytes & $\begin{array}{l}\text { Chondrodysplasia, disorganized chondrocytes in growth plate, defects in } \\
\text { chondrocyte proliferation, differentiation, increased apoptosis }\end{array}$ & Shu et al. 2011 \\
\hline $\mathrm{BMP} 2+4$ & $\begin{array}{l}\text { Limb bud } \\
\text { mesenchymal cells }\end{array}$ & $\begin{array}{l}\text { Failure of chondrogenic condensations to form normally, no formation of bone } \\
\text { marrow cavity, trabecular or cortical bone }\end{array}$ & Bandyopad-hyay et al. 2006 \\
\hline ВMP3 & All cells & Increased bone density & Daluiski et al. 2001 \\
\hline BMP5 & All cells & Short ear, brachypodism & King et al. 1994 \\
\hline BMP6 & All cells & Minor sternal defects & Solloway et al. 1998 \\
\hline BMP7 & All cells & Hindlimb polydactyly, defects in rib cage, skull & Luo et al. 1995 \\
\hline BMP11 & All cells & Anterior-posterior axial skeletal patterning defects & McPherron et al. 1999 \\
\hline Alk2 & Neural crest cells & $\begin{array}{l}\text { Craniofacial malformations, including cleft palate, hypotrophic mandible, } \\
\text { reduced ossification of frontal bone }\end{array}$ & Dudas et al. 2004 \\
\hline BMPR1A & Osteoblasts & Increased bone mass, decreased bone resorption, reduced osteoclastogenesis & Kamiya et al. 2008 \\
\hline BMPR1B & Osteoblasts & Decreased bone mineral density, bone volume, and bone formation & Zhao et al. 2002 \\
\hline Smad6 & All cells & $\begin{array}{l}\text { Axial and appendicular skeletal defects, posterior transformation of the cervical } \\
\text { vertebrae, bilateral ossification centers in lumbar vertebrae, incomplete sternal } \\
\text { band fusion, }\end{array}$ & Estrada et al. 2011 \\
\hline Smad1 & Chondrocytes & Delayed calvarial bone development & בר \\
\hline Smad1 & Osteoblasts & Osteopenia, impaired osteoblast proliferation and differentiation & 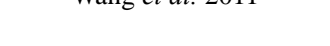 \\
\hline Noggin & Osteoblasts & Decreased weight, shortened femoral length, osteopenia & Canalis et al. 2012 \\
\hline
\end{tabular}

graft [109]. Treatment with rhBMP2 at the fracture site improved healing of patients with open tibial fractures [110]. rhBMP2 and rhBMP7 have subsequently been used to augment bone healing with improved fusion rates compared to autografts and fewer associated complications [83,91,93,94,99,100,102,104,111-114].

While BMP2 and BMP7 were initially identified by their ability to promote osteogenesis, it was unknown then if they were the most osteogenic BMPs. Subsequent studies have shown that osteogenic BMPs include 2, 4, 6, 7 and 9 [1,3,11,16,18,37,39,115-117]. Previously, the recombinant form of each BMP was unavailable and the osteogenic activity of all BMPs could not be analyzed. However, using adenoviral-mediated gene delivery into MSCs, we conducted a comprehensive analysis of the in vitro and in vivo osteogenic activity of 14 BMPs [11,13, 15-18]. We demonstrated BMP2, BMP6 and BMP9 as the most osteogenic BMPs, with BMP9 inducing the most potent osteogenic activity both in vitro and in vivo [11,13,18].

The osteogenic potential of BMP6 has been described both in vitro and in vivo [118-128]. AdBMP6-transduced equine bone marrow MSCs demonstrated enhanced osteoblastic differentiation with increased ALP activity, matrix mineralization and expression of osteogenic marker genes similar to AdBMP2 [128]. In a rabbit model, autologous bone marrow-derived osteoprogenitor cells exposed to an rhBMP6-containing extracellular matrix induced bone formation and enhanced spinal fusion [125]. In a rabbit ulnar osteotomy model, AdBMP6 accelerated bone formation and mineralization, leading to orthotopic bone formation when injected into the calf muscles of mice [118,124].

BMP9 has demonstrated potent osteoinduction in many studies including our comprehensive analysis of the osteogenic capacity of BMPs $[13,18]$, but it remains one of the least studied and most poorly characterized BMPs. Further investigation may show that BMP9 provides a better therapeutic avenue for the augmentation of bone regeneration than the BMPs currently used in the clinical setting.

\section{BMP9 INDUCES OSTEOGENIC DIFFERENTIATION}

Many investigations have described the osteogenic properties of BMP9, implicating its role in osteoblastic differentiation and bone regeneration. Adenoviral-mediated overexpression of BMP9 in C3H10T1/2 cells increased ALP activity and calcium deposition at significantly higher levels than BMP2 or BmP7 treatment groups. [11,45,66]. BMP3, a known inhibitor of BMP2 and BMP7-mediated osteogenesis, did not inhibit BMP9-mediated bone formation, suggesting that BMP9-mediated osteogenesis may occur via a distinct mechanism from other osteogenic BMPs [13].

Non-adenoviral delivery of BMP9 has also demonstrated potent osteoinduction of MSCs [129-131]. Direct sonoporation of rhBMP9 into mouse quadriceps muscles 
caused the formation of ectopic bone [131]. Nucleofection of human MSCs (hMSCs) with BMP9 caused bone formation at four weeks post-injection in vivo and significantly increased calcium deposition in vitro [129]. Treatment of MC3T3-E1 preosteoblastic cells with a peptide derived from BMP9 (pBMP-9) induced downstream phosphorylation of Smad uninhibited by noggin, a known extracellular antagonist of BMP2 and caused a dose-dependent increase in ALP activity, Runx2, Osterix, type 1 collagen and osteocalcin [132].

In vivo studies have confirmed BMP9 as a potent inducer of bone formation. BMP9-transduced C2C12 cells injected into the quadriceps muscles of mice demonstrated significant orthotopic bone formation [13,14,115]. AdBMP9 directly injected into the quadriceps muscles of mice and rats increased osteoid and mature lamellar bone formation in BMP9-treated group compared to BMP2and 7-treated groups, demonstrating that that skeletal muscle may harbor multipotent MSCs or osteoblastic progenitor cells [79,84,133]. Furthermore, the BMP9-induced ectopic bone was histologically determined to be the result of normal physiologic endochondral mechanisms.

BMP9 has demonstrated efficacy in non-union bone fracture repair and inducing spinal fusion in animal models [134,135]. Percutaneous paraspinal injection of AdBMP9-transduced hMSCs resulted in successful spinal fusion [134]. Non-union fracture was created in the radii of mice and filled with a collagen sponge electroporated with BMP9 plasmid; new bone was formed bridging the defect gap [135]. A defect in the radius of rabbits filled with an implant consisting of bone cement and AdBMP9 demonstrated more rapid callus and more bone formation compared to control and BMP2 treatment groups [136].

BMP9-induced bone formation demonstrates a distinct ossification pattern from other BMPs. In mice injected with AdBMP2 and 9-transduced C2C12 cells, increased bone maturation and marrow elements were seen in the BMP9-treated group [13]. When AdBMP9 was injected into the quadriceps muscles of mice and rats, primitive chondroblasts secreting a loose extracellular matrix was seen by six days, chondroblasts by nine days, areas of hypertrophic chondrocytes histologically similar to the epiphyseal end plate by 12 days, woven bone between days 12 and 19 and mature lamellar bone by three months [94]. These studies illustrate that the process of BMP9induced osteogenesis resembles the sequential physiologic phases of endochondral ossification which occur during the repair of bony fractures. While the specific mechanisms of BMP9-mediated osteogenesis remain to be defined, it appears that the BMP9-mediated osteogenic pathway is unique from that of other members of the BMP family and may provide a more effective, physiologic therapy for bone regeneration.

\section{CANONICAL BMP SIGNALING PATHWAY}

While the specific mechanisms governing for BMP9me-diated osteogenesis are largely unknown, much work has been done to elucidate the signaling pathways of the BMP family. And while many characteristics of BMP9 signaling are similar to other members of the BMP family, identification of the unique aspects of BMP9 signal transduction will allow us to better understand and utilize is potent osteogenic properties.

\subsection{BMP Ligands, BMP Type I and Type II Receptors Are Required for BMP Signaling}

Like other members of the TGF- $\beta$ superfamily, mature BMPs are secreted as a long precursor protein containing $\mathrm{N}$-terminal pro-region that is cleaved prior to secretion. However, the mature BMP9 protein retains this N-terminal pro-region, which does not inhibit the function of BMP9 and may actually stabilize it following secretion $[5,21,22$, 137-142].

The BMP signaling pathway is initiated upon BMP ligand binding to a heterodimeric Type I/Type II BMP transmembrane serine/threonine kinase receptor (BMPR1 and BMPR2); both must be active for signal transduction (Figure 2) [143,144]. Type II receptors are constitutively active and serve to phosphorylate and activate BMPR1 upon BMP ligand binding [145]. The phosphorylation site on Type I receptors is located near the C-terminal intracellular domain in a glycine-serine rich region termed the GS domain $[3,143]$.

While seven different type I receptors have been identified, only three type I receptors, ALK1, ALK5 and endoglin, are considered potential BMP9 type I receptors [137,146-148]. In fact, BMP9 has a poor affinity for BMPR-IA, a receptor that generally transduces BMP signaling [137]. Dominant negative mutations of the seven type I receptors demonstrated that only ALK1 and ALK2 mutants effectively inhibit BMP9-mediated osteogenic differentiation and bone formation [66]. ALK1 and 2 directly interacted with BMP9, and silencing of ALK1 and 2 inhibited BMP9-induced osteogenic differentiation of MSCs both in vitro and in vivo. These results strongly suggest that ALK1 and ALK2 are the type I BMPRs responsible for BMP9-mediated osteogenic signaling.

Type II BMP receptors are thought to be largely responsible for the osteogenic activity of BMPs, and four have been identified [45]. Dominant negative (DN) mutations introduced in two of these receptors, BMPRII and ActRII, decreased BMP9-induced ALP activity, expression of downstream Smad 6 and Smad 7, bone mineralization in vitro and ectopic bone formation in vivo [45]. These results strongly suggest that BMPRII and ActRII are the type II BMP receptors responsible for BMP9- 


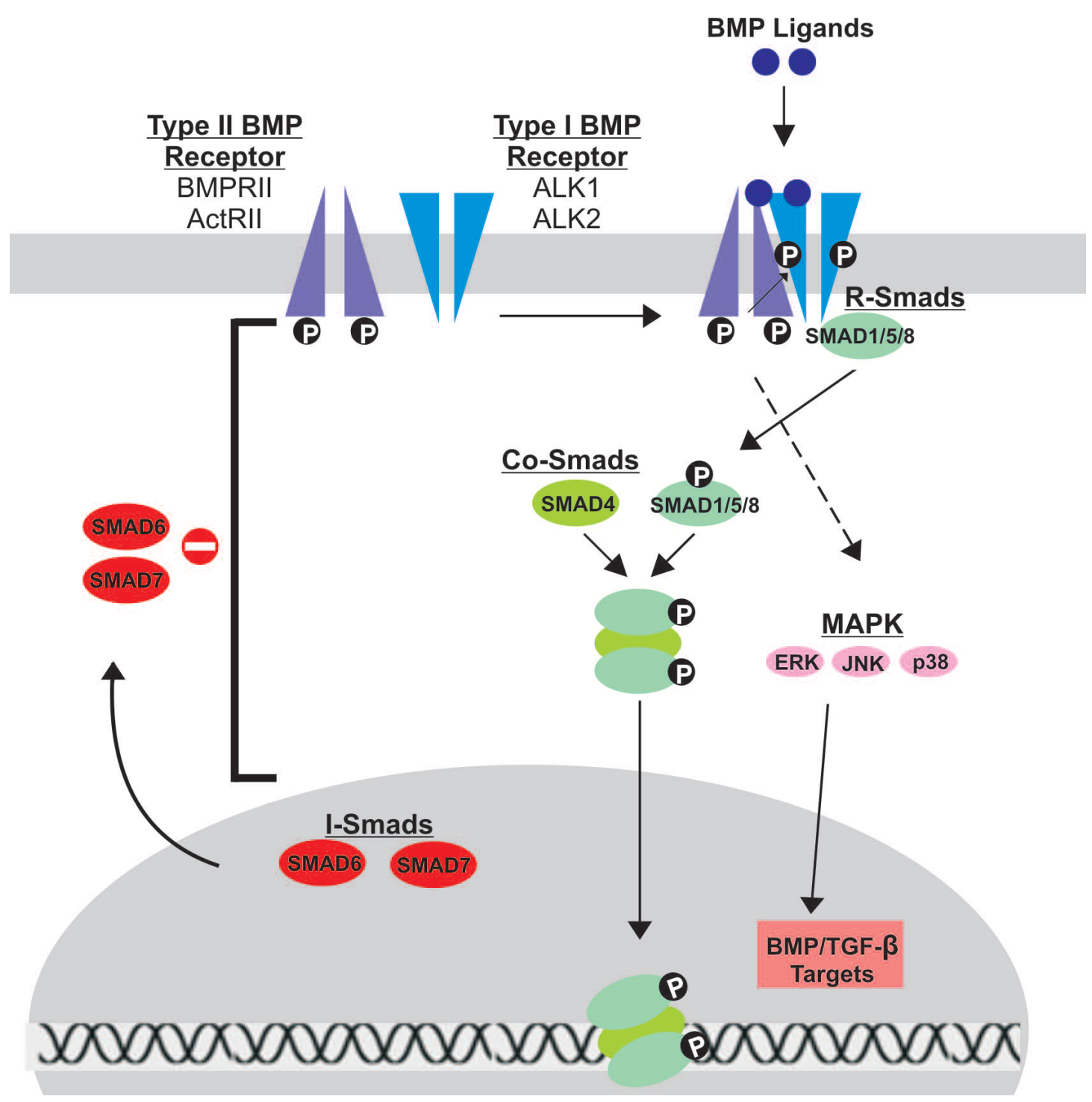

Figure 2. Schematic representation of BMP signal transduction. Upon BMP ligand binding to Type II BMP receptors, Type I BMP receptors are cross-phosphorylated, recruiting R-Smads (Smads 1/5/8) to the intracellular domain of the Type I receptor and initiating signal transduction via phosphorylation. Activated R-Smads then form a heteromeric complex with Co-Smads (Smad 4) before translocating to the nucleus to regulate gene expression. Inhibitory Smads (Smads 6/7) reside in the nucleus, migrate to the cytoplasm and negatively regulate BMP signaling by inhibiting signal transduction at several points along the pathway. The Type I and Type II receptors thought to be involved in BMP9 signal transduction are highlighted.

mediated osteogenic signaling.

\subsection{Smad-Dependent Signaling Is Required for BMP Osteogenic Signaling}

BMP binding to receptor heterodimers triggers one of two signaling pathways: Smad-dependent and Smadindependent. For the purpose of understanding the role of BMPs in osteogenesis, we will specifically focus on the Smad-dependent signaling pathway. There are 3 classes of Smads, all of which are important for BMP signal transduction [149]. Receptor-Smads (R-Smads) interact directly with activated type I receptors, while CommonSmads (co-Smads) form complexes with activated RSmads to then regulate gene expression in the nucleus. Inhibitory Smads (I-Smads) negatively regulate BMP signaling, inhibiting signal transduction at several points in the pathway.

The R-Smads, Smad1, Smad5 and Smad8, are activated upon binding and phosphorylation by the Type I receptor at a conserved sequence in the C-terminus termed the Ser-Ser-Val/Met-Ser sequence, or SSXS motif. Along with this conserved sequence, R-Smads have two additional regions of homology at the $\mathrm{N}$ and C-terminal ends, 
the Mad homology (MH) 1 and MH2 domains, both of which are crucial for proper signal transduction $[3,150]$. The MH1 domain directly interacts with DNA sequences, while the MH2 domain interacts with BMPR1. Additionally, the MH2 domain can bind to other Smads and has a role in transcriptional activation. These domains are conserved across co-Smads and I-Smads. Upon activation, the phosphorylated R-Smad dissociates from BMPR1 and forms a complex with Smad 4 [143,151,152]. Smad 4 is the sole Co-Smad and is common to all BMP signaling pathways. In the nucleus, the R-Smad/Co-Smad heterodimer complexes with various transcription factors, coactivators and corepressors to modulate gene expression.

The BMP signaling pathway is negatively regulated by I-Smads, Smad 6 and Smad 7. These Smads typically reside in the nucleus and migrate to the cytoplasm and plasma membrane upon BMP activation, acting at various points along the BMP pathway to inhibit signal transduction [1,151,153-157]. Smad7 binds to activated BMPR1, preventing R-Smads from becoming activated. Smad7 also interacts with E3 ubiquitin ligase proteins, Smurf1 and Smurf2, targeting the BMP receptor for proteasomal degradation. Unlike Smad 7, Smad 6 can bind directly to R-Smads, thus competing with Smad 4 and ultimately preventing proper heterodimer complex formation.

Activation of Smads was found to be necessary for BMP9-mediated osteogenic differentiation of MSCs [158]. Phosphorylated Smad 1/5/8 levels were simultaneously increased in BMP9-treated MSCs, while knockdown of Smad 4 resulted in reduced formation of Smad heterodimers and nuclear translocation of Smad 1/5/8; knockdown of Smad4 also inhibited BMP9-induced ALP activity and calcium deposition. The p38 inhibitor SB203580 decreased BMP9-induced Smad signaling in MSCs, while the ERK1/2 inhibitor PD98059 stimulated Smad signaling. Together, these findings suggest that activation of the Smads pathway is critical in BMP9-induced osteogenesis.

\section{MEDIATORS OF BMP9-INDUCED OSTEOGENIC SIGNALING}

Recent studies have identified various mediators thought to contribute to the potent osteogenic effects of BMP9. Among these mediators are Id genes, connective tissue growth factor (CTGF) and Hey1. Each of these three genes is among the most up-regulated following BMP9 stimulation of MSCs [24,26,139].

Balanced regulation of Id expression is important in lineage-specific MSC differentiation: Id genes are inhibitors of the binding of basic helix-loop-helix (bHLH) transcription factors [159-161] and function by dimerizing with bHLH proteins; these heterodimers are unable to bind DNA and regulate transcription. Id-1, -2 and -3 are among the most significantly up-regulated genes upon BMP9 stimulation [30]. However, both knockdown and overexpression of these three Id genes diminished BMP9induced osteogenic differentiation. BMP9-mediated Id expression was also shown to be dependent on Smad4 signaling.

Balanced regulation of CTGF expression is important in BMP9-induced osteogenic differentiation: Connective tissue growth factor (CTGF) is a member of the CCN (Cyr61, CTGF and Nov) family of secreted cysteine-rich multimodular proteins [162-167] and has a major role in bone formation and embryogenesis [168]. Upon BMP9stimulation of MSCs, CTGF was among the most upregulated genes, especially during early stages of differentiation [28]. Similar to Id genes, both knockdown and overexpression diminished BMP9-mediated osteogenic differentiation.

Hey 1 Expression Enhances BMP9-induced osteogenic differentiation via Runx2: Hey 1 (also known as Hesr1, HRT1, CHF2 and HERP2) is a nuclear protein of the Hairy/Enhancer of split-Related (HERP) family of basic helix-loop-helix transcriptional repressors and is a direct target of the Notch pathway [14]. Constitutive Hey 1 expression synergized with BMP9-induced osteogenic differentiation in vitro and in vivo [169], while Hey 1 silencing decreased osteogenic differentiation. Hey1 and the essential osteogenic transcription factor Runx2 synergized in BMP9-induced osteogenic differentiation, whereas Hey 1 silencing decreased Runx2 expression. Following knockdown of Hey 1, exogenous Runx2 expression rescued defective osteogenic signaling, strongly suggesting that Runx2 is a downstream mediator of Hey 1 signaling.

\section{MAJOR SIGNALING PATHWAYS CROSSTALK WITH BMP9 SIGNALING}

Several major signaling pathways with wide-ranging functions participate in BMP9-mediated osteogenesis, and many of these pathways are critical in the differentiation of other cell lineages. The following section describes recent studies illustrating the crosstalk between BMP9 signaling and these other important pathways. A brief description of each of these signaling pathways will be followed by a summary of results from recent studies.

TGF- $\beta 1$ is one of the most abundant members of the TGF- $\beta$ superfamily, regulating bone formation, osteoblast proliferation and mineralization while increasing the strength and flexibility of bone [170-173]. TGF- $\beta 1$ and BMPs both regulate the late phases of differentiation and mineralization of bone [138,174-176].

Growth hormone (GH) plays a critical role in postnatal growth [177-184]. GH signaling pathway begins when 
GH binds GHR, triggering receptor tyrosine kinase activity and activation of JAK/STAT and other pathways $[178,179,184]$. IGF-2 is a member of the IGF signaling system, playing a critical role in prenatal growth and development [185]. IGF-2 signaling activates the phosphatidylinositol-3-kinase (PI3K)/AKT pathway or the mitogen-activated protein kinase pathway (MAPK) [186].

Wnts are a family of secreted proteins critical in osteoblastic differentiation and skeletal development [16, 116,187-193]. Upon Wnt binding the Frizzled (Frz) and LRP-5/6 co-receptors, distinct signaling pathways including the canonical Wnt pathway are activated [194]; mutations in LRP-5 adversely affect skeletal development and bone mass deposition [195].

MAPKs are protein kinases critical in regulation of gene expression, mitosis, metabolism, motility, survival, apoptosis and differentiation [21,158,196-199]. Members of the MAPK family become activated by BMPs in response to a variety of extracellular stimuli leading to diverse effects in cellular responses [198-201]. Hypoxia inducible factor 1 Alpha (HIF1 $\alpha$ ) is a regulator of angiogenesis during many developmental processes, including skeletal development [64,202].

Peroxisome proliferator-activated receptor gamma (PPAR- $\gamma$ ) is a critical regulator of adipogenesis and osteogenesis [203,204]. PPAR- $\gamma$ binds fatty acid derivatives to induce differentiation of preadipocytes into terminal adipocytes, and PPAR- $\gamma 2$ is the predominant isoform expressed in adipose tissue [81,159,161]. Retinoic acids (RAs) play a crucial role during embryonic development and in the maintenance of vital organs $[38,39]$. RAs are ligands for two families of receptors, the RA receptors (RAR) that bind all-trans-RA (ATRA) and the Retinoid X Receptors (RXR) that bind 9-cis-RA (9CRA) [205,206]. RA binding to RAR/RXR causes heterodimerization and eventual transcriptional regulation [206].

\section{Effects of Crosstalk Pathways on BMP9-Induced Osteogenic Differentiation}

TGF- $\beta 1$ has a biphasic effect on BMP9-induced osteogenic differentiation of MSCs: In BMP9-transduced MSCs, low concentrations of recombinant TGF- $\beta 1$ (rhTGF- $\beta 1$ ) synergistically induced expression of ALP and matrix mineralization, while high concentrations of TGF- $\beta 1$ inhibited BMP9-induced osteogenic activity [175].

GH synergizes with BMP9 via activation of the JAK/ STAT/IGF1 pathway to induce osteogenesis: After overexpression of BMP9 in MSCs, GH was one of the most up-regulated transcripts [158]. Exogenous GH synergized with BMP9 to induce early and late osteogenic markers. Co-stimulation of long-bone explants with GH and BMP9 resulted in significant expansion of the growth plate, and co-stimulation of MSCs with BMP9 and GH formed mature ectopic bone masses; these synergistic effects of BMP9 and GH were inhibited by JAK/STAT inhibitors.

BMP9 signaling crosstalks with IGF-2 via PI3K/AKT signaling: While endogenous IGF-2 levels are relatively low in MSCs, exogenous expression of IGF-2 potentiates BMP9-induced expression of early and late osteogenic markers [207]. Conversely, PI3K inhibition diminished IGF-2 potentiation on BMP9-mediated osteogenesis. IGF2 augmented BMP9-induced ectopic bone formation and BMP9-mediated endochondral ossification in perinatal limb explants.

The canonical Wnt/ $\beta$-catenin pathway interacts with Runx2 as a critical mediator of BMP9-mediated osteogenic signaling: Wnt3a and BMP9 synergized to induce ALP activity in MSCs, while the Wnt antagonist FrzB inhibited BMP9-induced ALP activity [194]. BMP9 stimulation of MSCs recruits $\beta$-catenin and Runx2 to the osteocalcin promoter, whereas knockdown of $\beta$-catenin decreased expression of early and late osteogenic markers [194]. BMP9-induced ectopic bone formation and matrix mineralization in vivo were inhibited by FrzB overexpression or $\beta$-catenin knockdown [194].

p38 and ERK1/2 have opposing regulatory effects in BMP9-induced osteogenic differentiation of MSCs via Smad signaling: BMP9 simultaneously promotes phosphorylation and thus activation of Smads, p38 and ERK1/2 [158]. p38 and ERK1/2 acted in opposition to regulate BMP9-mediated osteogenic differentiation via interactions with Smads. In vivo, inhibition of p38 significantly decreased BMP9-induced osteogenic differentiation, while inhibition of ERK1/2 significantly increased BMP9-induced osteogenic differentiation [208].

$H I F 1 \alpha$ synergizes with BMP9-induced osteogenic differentiation of MSCs: Exogenous overexpression of HIF1 $\alpha$ synergistically increased BMP9-induced osteogenic differentiation of MSCs. Conversely, inhibition of HIF1 $\alpha$ diminished BMP9-induced osteogenic signaling. BMP9 directly induced HIF1 $\alpha$ expression in MSCs via Smad1/ 5/8 signaling [209]. HIF1 $\alpha$ activated both angiogenic and osteogenic signaling pathways in MSCs. Osteogenic factors, including BMP9, may induce the convergence of osteogenic and angiogenic signaling in MSC differentiation, thereby enhancing the efficiency of bone formation and development.

PPAR- $\gamma$ is an important regulator of BMP9-mediated osteogenesis: Overexpression of PPAR- $\gamma 2$ in BMP-9stimulated MSCs promoted both osteogenic and adipogenic differentiation, with mutually exclusive commitment to either lineage [18]. Conversely, knockdown of PPAR- $\gamma 2$ in BMP9-stimulated MSCs showed significant decreases in osteogenic differentiation and matrix mineralization.

Retinoic acids synergistically enhance BMP9-mediated osteoinduction of MSCs: Both ATRA and 9CRA induced 
expression of BMP9, activated BMPRSmad transcription activity and increased expression of early and late osteogenic markers; these effects were synergistic when combined with overexpression of BMP9 [210]. RAs combined with BMP9 promoted expansion of the hypertrophic chondrocyte zone in neonatal mouse limb explants, and RARs synergized with BMP9 to induce trabecular bone formation and osteoid matrix production in vivo.

\section{OTHER FUNCTIONS OF BMP9}

BMP9 is known to be a potent osteogenic factor, but it also influences several other pathways including cancer development and angiogenesis. While some studies have shown BMP9 to restrict tumor growth through diverse mechanisms [211-213], other studies have shown BMP9 to promote cancer progression [214]. BMP9 inhibited cell migration and induce apoptosis of osteosarcoma via the PI3K/ALT pathway [212] slowed tumor growth of colon adenocarcinoma via inhibitory effects on angiogenesis via the ALK1 receptor and endoglin coreceptor [211]. Conversely, BMP9 induced in vivo angiogenesis within pancreatic tumors [214]. The effects of BMP9 on angiogenesis remain controversial as well, with some studies demonstrating a pro-angiogenic effect $[215,216]$ and others an anti-angiogenic effect [146,217-219]. It is evident that the effects of BMP9 on angiogenesis and cancer progression remain to be fully elucidated.

BMP9 also modulates neurogenesis, hepatocellular regeneration, adipogenesis, chondrogenesis and myogenesis. Several studies have demonstrated BMP9 to promote the cholinergic phenotype neurologically [220-223]. BMP9 also acts as a hepatic insulin-sensitizing substance and may play a role in hepatocellular regeneration [224,225]. BMP9 promotes adipogenesis [18] and also upregulates Sox9 expression to induce chondrogenic differentiation [226,227]. While BMP9 promotes MSC differentiation along osteogenic, adipogenic and chondrogenic lines to varying degrees, it inhibits the myogenic phenotype [29]. Overall, BMP9 has diverse effects beyond osteogenesis.

\section{CONCLUDING REMARKS AND FUTURE DIRECTIONS}

The investigations discussed here demonstrate the critical role of BMPs, particularly BMP9, in the osteogenic differentiation of MSCs. The findings discussed here strongly support the notion that BMP9 may provide a more effective clinical strategy for the augmentation of bone regeneration and healing than other BMPs. Furthermore, studies demonstrating that BMP9-mediated osteogenesis resembles the physiologic phases of bone healing occurring during fracture repair make the prospect of clinical translation quite promising. With several diverse signaling pathways enhancing BMP9-mediated osteoge- nesis, further elucidation of these specific pathways will allow for the development of improved therapies. Over the last decade, there has been a substantial increase in the therapeutic use of recombinant proteins and medications targeting small molecules acting in various signaling pathways. With this, it is imperative that the mechanisms underlying BMP9-mediated osteogenesis become fully elucidated to allow for the development of much-needed clinical therapies.

\section{ACKNOWLEDGEMENTS}

The reported work was supported in part by research grants from the OREF and the National Institutes of Health (RCH, TCH and HHL). JDL was the recipient of the Pritzker Research Fellowship from The University of Chicago Pritzker School of Medicine and the Alpha Omega Alpha Carolyn L. Kuckein Student Research Fellowship.

\section{REFERENCES}

[1] Attisano, L. and Wrana, J.L. (2002) Signal transduction by the TGF-beta superfamily. Science, 296, 1646-1647. doi:10.1126/science.1071809

[2] Hogan, B.L. (1996) Bone morphogenetic proteins in development. Current Opinion in Genetics \& Development, 6, 432-438. doi:10.1016/S0959-437X(96)80064-5

[3] Shi, Y. and Massague, J. (2003) Mechanisms of TGFbeta signaling from cell membrane to the nucleus. Cell, 113, 685-700. doi:10.1016/S0092-8674(03)00432-X

[4] Varga, A.C. and Wrana, J.L. (2005) The disparate role of BMP in stem cell biology. Oncogene, 24, 5713-5721. doi:10.1038/sj.onc.1208919

[5] Zhang, J. and Li, L. (2005) BMP signaling and stem cell regulation. Developmental Biology, 284, 1-11. doi:10.1016/j.ydbio.2005.05.009

[6] Christiansen, J.H., Coles, E.G. and Wilkinson, D.G. (2000) Molecular control of neural crest formation, migration and differentiation. Current Opinion in Cell Biology, 12, 719-724. doi:10.1016/S0955-0674(00)00158-7

[7] Derynck, R. and Feng, X.H. (1997) TGF-beta receptor signaling. Biochimica et Biophysica Acta, 1333, F105F150.

[8] Di Cesare, P.E., Frenkel, S.R., Carlson, C.S., Fang, C. and Liu, C. (2006) Regional gene therapy for full-thickness articular cartilage lesions using naked DNA with a collagen matrix. Journal of Orthopaedic Research, 24, 1118-1127.

[9] Hu, J., Chen, Y.X., Wang, D., Qi, X., Li, T.G., Hao, J., Mishina, Y., Garbers, D.L. and Zhao, G.Q. (2004) Developmental expression and function of Bmp4 in spermatogenesis and in maintaining epididymal integrity. Developmental Biology, 276, 158-171. doi:10.1016/j.ydbio.2004.08.034

[10] Kuo, A.C., Rodrigo, J.J., Reddi, A.H., Curtiss, S., Grotkopp, E. and Chiu, M. (2006) Microfracture and bone morphogenetic protein 7 (BMP-7) synergistically stimulate articular cartilage repair. Osteoarthritis and Cartilage, 


\section{4, 1126-1135. doi:10.1016/j.joca.2006.04.004}

[11] Luu, H.H., Song, W.X., Luo, X., Manning, D., Luo, J., Deng, Z.L., Sharff, K.A., Montag, A.G., Haydon, R.C. and He, T.C. (2007) Distinct roles of bone morphogenetic proteins in osteogenic differentiation of mesenchymal stem cells. Journal of Orthopaedic Research, 25, 665-677. doi:10.1002/jor.20359

[12] Mitu, G. and Hirschberg, R. (2008) Bone morphogenetic protein-7 (BMP7) in chronic kidney disease. Frontiers in Bioscience, 13, 4726-4739.

[13] Kang, Q., Sun, M.H., Cheng, H., Peng, Y., Montag, A.G., Deyrup, A.T., Jiang, W., Luu, H.H., Luo, J., Szatkowski, J.P., Vanichakarn, P., Park, J.Y., Li, Y., Haydon, R.C. and He, T.C. (2004) Characterization of the distinct orthotopic bone-forming activity of 14 BMPs using recombinant adenovirus-mediated gene delivery. Gene Therapy, 11, 1312-1320. doi:10.1038/sj.gt.3302298

[14] Luther, G., Wagner, E.R., Zhu, G., Kang, Q., Luo, Q., Lamplot, J., Bi, Y., Luo, X., Luo, J., Teven, C., Shi, Q., Kim, S.H., Gao, J.L., Huang, E., Yang, K., Rames, R., Liu, X., Li, M., Hu, N., Liu, H., Su, Y., Chen, L., He, B.C., Zuo, G.W., Deng, Z.L., Reid, R.R., Luu, H.H., Haydon, R.C. and He, T.C. (2011) BMP-9 induced osteogenic differentiation of mesenchymal stem cells: Molecular mechanism and therapeutic potential. Current Gene Therapy, 11, 229-240. doi:10.2174/156652311795684777

[15] Aubin, J.E. (2001) Regulation of osteoblast formation and function. Reviews in Endocrine and Metabolic Disorders, 2, 81-94. doi:10.1023/A:1010011209064

[16] Deng, Z.L., Sharff, K.A., Tang, N., Song, W.X., Luo, J., Luo, X., Chen, J., Bennett, E., Reid, R., Manning, D., Xue, A., Montag, A.G., Luu, H.H., Haydon, R.C. and He, T.C. (2008) Regulation of osteogenic differentiation during skeletal development. Frontiers in Bioscience, 13, 2001-2021. doi:10.2741/2819

[17] He, B.C., Chen, L., Zuo, G.W., Zhang, W., Bi, Y., Huang, J., Wang, Y., Jiang, W., Luo, Q., Shi, Q., Zhang, B.Q., Liu, B., Lei, X., Luo, J., Luo, X., Wagner, E.R., Kim, S.H., He, C.J., Hu, Y., Shen, J., Zhou, Q., Rastegar, F., Deng, Z.L., Luu, H.H., He, T.C. and Haydon, R.C. (2010) Synergistic antitumor effect of the activated PPARgamma and retinoid receptors on human osteosarcoma. Clinical Cancer Research, 16, 2235-2245. doi:10.1158/1078-0432.CCR-09-2499

[18] Kang, Q., Song, W.X., Luo, Q., Tang, N., Luo, J., Luo, X., Chen, J., Bi, Y., He, B.C., Park, J.K., Jiang, W., Tang, Y., Huang, J., Su, Y., Zhu, G.H., He, Y., Yin, H., Hu, Z., Wang, Y., Chen, L., Zuo, G.W., Pan, X., Shen, J., Vokes, T., Reid, R.R., Haydon, R.C., Luu, H.H. and He, T.C. (2009) A comprehensive analysis of the dual roles of BMPs in regulating adipogenic and osteogenic differenttiation of mesenchymal progenitor cells. Stem Cells and Development, 18, 545-559. doi:10.1089/scd.2008.0130

[19] Urist, M.R. (1965) Bone: Formation by autoinduction. Science, 150, 893-899. doi:10.1126/science.150.3698.893

[20] Wozney, J.M., Rosen, V., Celeste, A.J., Mitsock, L.M., Whitters, M.J., Kriz, R.W., Hewick, R.M. and Wang, E.A. (1988) Novel regulators of bone formation: Molecular clones and activities. Science, 242, 1528-1534. doi:10.1126/science.3201241

[21] Hogan, B.L. (1996) Bone morphogenetic proteins: Multifunctional regulators of vertebrate development. Genes \& Development, 10, 1580-1594. doi:10.1101/gad.10.13.1580

[22] Zhao, G.Q. (2003) Consequences of knocking out BMP signaling in the mouse. Genesis, 35, 43-56. doi:10.1002/gene.10167

[23] Song, J.J., Celeste, A.J., Kong, F.M., Jirtle, R.L., Rosen, V. and Thies, R.S. (1995) Bone morphogenetic protein-9 binds to liver cells and stimulates proliferation. Endocrinology, 136, 4293-4297. doi:10.1210/en.136.10.4293

[24] Chen, C., Grzegorzewski, K.J., Barash, S., Zhao, Q., Schneider, H., Wang, Q., Singh, M., Pukac, L., Bell, A.C., Duan, R., Coleman, T., Duttaroy, A., Cheng, S., Hirsch, J., Zhang, L., Lazard, Y., Fischer, C., Barber, M.C., Ma, Z.D., Zhang, Y.Q., Reavey, P., Zhong, L., Teng, B., Sanyal, I., Ruben, S.M., Blondel, O. and Birse, C.E. (2003) An integrated functional genomics screening program reveals a role for BMP-9 in glucose homeostasis. Nature Biotechnology, 21, 294-301.

[25] Lopez-Coviella, I., Berse, B., Krauss, R., Thies, R.S. and Blusztajn, J.K. (2000) Induction and maintenance of the neuronal cholinergic phenotype in the central nervous system by BMP-9. Science, 289, 313-316. doi:10.1126/science.289.5477.313

[26] Truksa, J., Peng, H., Lee, P. and Beutler, E. (2006) Bone morphogenetic proteins 2, 4, and 9 stimulate murine hepcidin 1 expression independently of Hfe, transferrin receptor 2 (Tfr2), and IL-6. Proceedings of the National Academy of Sciences of the United States of America, 103, 10289-10293. doi:10.1073/pnas.0603124103

[27] Cheng, H., Jiang, W., Phillips, F.M., Haydon, R.C., Peng, Y., Zhou, L., Luu, H.H., An, N., Breyer, B., Vanichakarn, P., Szatkowski, J.P., Park, J.Y. and He, T.C. (2003) Osteogenic activity of the fourteen types of human bone morphogenetic proteins (BMPs). The Journal of Bone and Joint Surgery. American Volume, 85-A, 1544-1552.

[28] Luo, Q., Kang, Q., Si, W., Jiang, W., Park, J.K., Peng, Y., Li, X., Luu, H.H., Luo, J., Montag, A.G., Haydon, R.C. and He, T.C. (2004) Connective tissue growth factor (CTGF) is regulated by wnt and bone morphogenetic proteins signaling in osteoblast differentiation of mesenchymal stem cells. The Journal of Biological Chemistry, 279, 55958-55968. doi:10.1074/jbc.M407810200

[29] Peng, Y., Kang, Q., Cheng, H., Li, X., Sun, M.H., Jiang, W., Luu, H.H., Park, J.Y., Haydon, R.C. and He, T.C. (2003) Transcriptional characterization of bone morphogenetic proteins (BMPs)-mediated osteogenic signaling. Journal of Cellular Biochemistry, 90, 1149-1165. doi:10.1002/jcb.10744

[30] Peng, Y., Kang, Q., Luo, Q., Jiang, W., Si, W., Liu, B.A., Luu, H.H., Park, J.K., Li, X., Luo, J., Montag, A.G., Haydon, R.C. and He, T.C. (2004) Inhibitor of DNA binding/differentiation helix-loop-helix proteins mediate bone morphogenetic protein-induced osteoblast differentiation of mesenchymal stem cells. The Journal of Biological Chemistry, 279, 32941-32949. 
doi:10.1074/jbc.M403344200

[31] Karsenty, G. (1999) The genetic transformation of bone biology. Genes \& Development, 13, 3037-3051. doi:10.1101/gad.13.23.3037

[32] Lian, J.B., Stein, G.S., Stein, J.L. and van Wijnen, A.J. (1998) Transcriptional control of osteoblast differentiation. Biochemical Society Transactions, 26, 14-21.

[33] Reddi, A.H. (1997) Bone morphogenetic proteins: An unconventional approach to isolation of first mammalian morphogens. Cytokine \& Growth Factor Reviews, 8, 1120. doi:10.1016/S1359-6101(96)00049-4

[34] Lin, G.L. and Hankenson, K.D. (2011) Integration of BMP, Wnt, and notch signaling pathways in osteoblast differentiation. Journal of Cellular Biochemistry, 112, 3491-3501. doi:10.1002/jcb.23287

[35] Marcellini, S., Henriquez, J.P. and Bertin, A. (2012) Control of osteogenesis by the canonical Wnt and BMP pathways in vivo: Cooperation and antagonism between the canonical Wnt and BMP pathways as cells differentiate from osteochondroprogenitors to osteoblasts and osteocytes. Bioessays, 34, 953-962. doi:10.1002/bies.201200061

[36] Olsen, B.R., Reginato, A.M. and Wang, W. (2000) Bone development. Annual Review of Cell and Developmental Biology, 16, 191-220. doi:10.1146/annurev.cellbio.16.1.191

[37] Ducy, P. and Karsenty, G. (2000) The family of bone morphogenetic proteins. Kidney International, 57, 22072214. doi:10.1046/j.1523-1755.2000.00081.x

[38] Ducy, P., Starbuck, M., Priemel, M., Shen, J., Pinero, G., Geoffroy, V., Amling, M. and Karsenty, G. (1999) A Cbfa1-dependent genetic pathway controls bone formation beyond embryonic development. Genes \& Development, 13, 1025-1036. doi:10.1101/gad.13.8.1025

[39] Reddi, A.H. (1998) Role of morphogenetic proteins in skeletal tissue engineering and regeneration. Nature Biotechnology, 16, 247-252.

[40] Harada, S. and Rodan, G.A. (2003) Control of osteoblast function and regulation of bone mass. Nature, 423, 349355.

[41] Ralston, S.H. and de Crombrugghe, B. (2006) Genetic regulation of bone mass and susceptibility to osteoporosis. Genes \& Development, 20, 2492-2506. doi:10.1101/gad.1449506

[42] King, J.A., Marker, P.C., Seung, K.J. and Kingsley, D.M. (1994) BMP5 and the molecular, skeletal, and soft-tissue alterations in short ear mice. Developmental Biology, 166, 112-122. doi:10.1006/dbio.1994.1300

[43] Hall, P.A. and Watt, F.M. (1989) Stem cells: The generation and maintenance of cellular diversity. Development, 106, 619-633.

[44] Tsumaki, N. and Yoshikawa, H. (2005) The role of bone morphogenetic proteins in endochondral bone formation. Cytokine \& Growth Factor Reviews, 16, 279-285. doi:10.1016/j.cytogfr.2005.04.001

[45] Wu, N., Zhao, Y., Yin, Y., Zhang, Y. and Luo, J. (2010) Identification and analysis of type II TGF-beta recaptors in BMP-9-induced osteogenic differentiation of C3H10T1/2 mesenchymal stem cells. Acta Biochimica et Biophysica Sinica, 42, 699-708. doi:10.1093/abbs/gmq075

[46] Wu, X., Shi, W. and Cao, X. (2007) Multiplicity of BMP signaling in skeletal development. Annals of the New York Academy of Sciences, 1116, 29-49. doi:10.1196/annals.1402.053

[47] Shu, B., Zhang, M., Xie, R., Wang, M., Jin, H., Hou, W., Tang, D., Harris, S.E., Mishina, Y., O’Keefe, R.J., Hilton, M.J., Wang, Y. and Chen, D. (2011) BMP2, but not BMP4, is crucial for chondrocyte proliferation and maturation during endochondral bone development. Journal of Cell Science, 124, 3428-3440. doi:10.1242/jcs.083659

[48] Estrada, K.D., Retting, K.N., Chin, A.M. and Lyons, K.M. (2011) Smad6 is essential to limit BMP signaling during cartilage development. Journal of Bone and Mineral Research, 26, 2498-2510.

[49] Pan, Q., Yu, Y., Chen, Q., Li, C., Wu, H., Wan, Y., Ma, J. and Sun, F. (2008) Sox9, a key transcription factor of bone morphogenetic protein-2-induced chondrogenesis, is activated through BMP pathway and a CCAAT box in the proximal promoter. Journal of Cellular Physiology, 217, 228-241. doi:10.1002/jcp.21496

[50] Zehentner, B.K., Dony, C. and Burtscher, H. (1999) The transcription factor Sox9 is involved in BMP-2 signaling. Journal of Bone and Mineral Research, 14, 1734-1741. doi:10.1359/jbmr.1999.14.10.1734

[51] Wang, M., Jin, H., Tang, D., Huang, S., Zuscik, M.J. and Chen, D. (2011) Smad1 plays an essential role in bone development and postnatal bone formation. Osteoarthritis and Cartilage, 19, 751-762. doi:10.1016/j.joca.2011.03.004

[52] Yoon, B.S. and Lyons, K.M. (2004) Multiple functions of BMPs in chondrogenesis. Journal of Cellular Biochemistry, 93, 93-103. doi:10.1002/jcb.20211

[53] Canalis, E., Brunet, L.J., Parker, K. and Zanotti, S. (2012) Conditional inactivation of noggin in the postnatal skeleton causes osteopenia. Endocrinology, 153, 1616-1626. doi:10.1210/en.2011-1604

[54] Smith, W.C. and Harland, R.M. (1992) Expression cloning of noggin, a new dorsalizing factor localized to the Spemann organizer in Xenopus embryos. Cell, 70, 829840. doi:10.1016/0092-8674(92)90316-5

[55] Valenzuela, D.M., Economides, A.N., Rojas, E., Lamb, T.M., Nunez, L., Jones, P., Lp, N.Y., Espinosa 3rd, R., Brannan, C.I., Gilbert, D.J., et al. (1995) Identification of mammalian noggin and its expression in the adult nervous system. The Journal of Neuroscience, 15, 6077-6084.

[56] Zimmerman, L.B., De Jesus-Escobar, J.M. and Harland, R.M. (1996) The Spemann organizer signal noggin binds and inactivates bone morphogenetic protein 4. Cell, $\mathbf{8 6}$, 599-606. doi:10.1016/S0092-8674(00)80133-6

[57] Devlin, R.D., Du, Z., Pereira, R.C., Kimble, R.B., Economides, A.N., Jorgetti, V. and Canalis, E. (2003) Skeletal overexpression of noggin results in osteopenia and reduced bone formation. Endocrinology, 144, 1972-1978. doi:10.1210/en.2002-220918 
[58] Brunet, L.J., McMahon, J.A., McMahon, A.P. and Harland, R.M. (1998) Noggin, cartilage morphogenesis, and joint formation in the mammalian skeleton. Science, 280, 1455-1457. doi:10.1126/science.280.5368.1455

[59] Kamiya, N., Kobayashi, T., Mochida, Y., Yu, P.B., Yamauchi, M., Kronenberg, H.M. and Mishina, Y. (2009) Wnt inhibitors Dkk1 and Sost are downstream targets of BMP signaling through the type IA receptor (BMPRIA) in osteoblasts. Journal of Bone and Mineral Research, 25, 200-210. doi:10.1359/jbmr.090806

[60] Kamiya, N., Ye, L., Kobayashi, T., Lucas, D.J., Mochida, Y., Yamauchi, M., Kronenberg, H.M., Feng, J.Q. and Mishina, Y. (2008) Disruption of BMP signaling in osteoblasts through type IA receptor (BMPRIA) increases bone mass. Journal of Bone and Mineral Research, 23, 2007-2017. doi:10.1359/jbmr.080809

[61] Kamiya, N., Ye, L., Kobayashi, T., Mochida, Y., Yamauchi, M., Kronenberg, H.M., Feng, J.Q. and Mishina, Y. (2008) BMP signaling negatively regulates bone mass through sclerostin by inhibiting the canonical Wnt pathway. Development, 135, 3801-3811. doi:10.1242/dev.025825

[62] Zhao, M., Harris, S.E., Horn, D., Geng, Z., Nishimura, R., Mundy, G.R. and Chen, D. (2002) Bone morphogenetic protein receptor signaling is necessary for normal murine postnatal bone formation. Journal of Cellular Biochemistry, 157, 1049-1060. doi:10.1083/jcb.200109012

[63] Francis-West, P.H., Tatla, T. and Brickell, P.M. (1994) Expression patterns of the bone morphogenetic protein genes Bmp-4 and Bmp-2 in the developing chick face suggest a role in outgrowth of the primordia. Developmental Dynamics, 201, 168-178. doi:10.1002/aja.1002010207

[64] Wan, C., Shao, J., Gilbert, S.R., Riddle, R.C., Long, F., Johnson, R.S., Schipani, E. and Clemens, T.L. (2010) Role of HIF-1alpha in skeletal development. Annals of the New York Academy of Sciences, 1192, 322-326. doi:10.1111/j.1749-6632.2009.05238.x

[65] Kanzler, B., Foreman, R.K., Labosky, P.A. and Mallo, M. (2000) BMP signaling is essential for development of skeletogenic and neurogenic cranial neural crest. Development, 127, 1095-1104.

[66] Luo, J., Tang, M., Huang, J., He, B.C., Gao, J.L., Chen, L., Zuo, G.W., Zhang, W., Luo, Q., Shi, Q., Zhang, B.Q., Bi, Y., Luo, X., Jiang, W., Su, Y., Shen, J., Kim, S.H., Huang, E., Gao, Y., Zhou, J.Z., Yang, K., Luu, H.H., Pan, X., Haydon, R.C., Deng, Z.L. and He, T.C. (2010) TGFbeta/BMP type I receptors ALK1 and ALK2 are essential for BMP9-induced osteogenic signaling in mesenchymal stem cells. The Journal of Biological Chemistry, 285, 29588-29598. doi:10.1074/jbc.M110.130518

[67] Dudas, M., Sridurongrit, S., Nagy, A., Okazaki, K. and Kaartinen, V. (2004) Craniofacial defects in mice lacking BMP type I receptor Alk2 in neural crest cells. Mechanisms of Development, 121, 173-182. doi:10.1016/j.mod.2003.12.003

[68] Bandyopadhyay, A., Tsuji, K., Cox, K., Harfe, B.D., Rosen, V. and Tabin, C.J. (2006) Genetic analysis of the roles of BMP2, BMP4, and BMP7 in limb patterning and skeletogenesis. PLoS Genetics, 2, e216. doi:10.1371/journal.pgen.0020216

[69] Dudley, A.T., Lyons, K.M. and Robertson, E.J. (1995) A requirement for bone morphogenetic protein-7 during development of the mammalian kidney and eye. Genes \& Development, 9, 2795-2807. doi:10.1101/gad.9.22.2795

[70] Luo, G., Hofmann, C., Bronckers, A.L., Sohocki, M., Bradley, A. and Karsenty, G. (1995) BMP-7 is an inducer of nephrogenesis, and is also required for eye development and skeletal patterning. Genes \& Development, $\mathbf{9}$, 2808-2820. doi:10.1101/gad.9.22.2808

[71] Solloway, M.J., Dudley, A.T., Bikoff, E.K., Lyons, K.M., Hogan, B.L. and Robertson, E.J. (1998) Mice lacking Bmp6 function. Developmental Genetics, 22, 321-339. doi:10.1002/(SICI)1520-6408(1998)22:4<321::AID-DV G3>3.0.CO;2-8

[72] McPherron, A.C., Lawler, A.M. and Lee, S.J. (1999) Regulation of anterior/posterior patterning of the axial skeleton by growth/differentiation factor 11. Nature Genetics, 22, 260-264. doi:10.1038/10320

[73] Daluiski, A., Engstrand, T., Bahamonde, M.E., Gamer, L.W., Agius, E., Stevenson, S.L., Cox, K., Rosen, V. and Lyons, K.M. (2001) Bone morphogenetic protein-3 is a negative regulator of bone density. Nature Genetics, 27, 84-88. doi: $10.1038 / 83810$

[74] Winnier, G., Blessing, M., Labosky, P.A. and Hogan, B.L. (1995) Bone morphogenetic protein-4 is required for mesoderm formation and patterning in the mouse. Genes \& Development, 9, 2105-2116. doi:10.1101/gad.9.17.2105

[75] Alden, T.D., Pittman, D.D., Beres, E.J., Hankins, G.R., Kallmes, D.F., Wisotsky, B.M., Kerns, K.M. and Helm, G.A. (1999) Percutaneous spinal fusion using bone morphogenetic protein-2 gene therapy. Journal of Neurosurgery, 90, 109-114.

[76] Alden, T.D., Pittman, D.D., Hankins, G.R., Beres, E.J., Engh, J.A., Das, S., Hudson, S.B., Kerns, K.M., Kallmes, D.F. and Helm, G.A. (1999) In vivo endochondral bone formation using a bone morphogenetic protein 2 adenoviral vector. Human Gene Therapy, 10, 2245-2253. doi:10.1089/10430349950017220

[77] Baltzer, A.W., Lattermann, C., Whalen, J.D., Ghivizzani, S., Wooley, P., Krauspe, R., Robbins, P.D. and Evans, C.H. (2000) Potential role of direct adenoviral gene transfer in enhancing fracture repair. Clinical Orthopaedics and Related Research, S120-S125.

[78] Baltzer, A.W., Lattermann, C., Whalen, J.D., Wooley, P., Weiss, K., Grimm, M., Ghivizzani, S.C., Robbins, P.D. and Evans, C.H. (2000) Genetic enhancement of fracture repair: Healing of an experimental segmental defect by adenoviral transfer of the BMP-2 gene. Gene Therapy, 7, 734-739. doi:10.1038/sj.gt.3301166

[79] Bosch, P., Musgrave, D., Ghivizzani, S., Latterman, C., Day, C.S. and Huard, J. (2000) The efficiency of musclederived cell-mediated bone formation. Cell Transplant, $\mathbf{9}$, 463-470.

[80] Breitbart, A.S., Grande, D.A., Mason, J.M., Barcia, M., James, T. and Grant, R.T. (1999) Gene-enhanced tissue 
engineering: Applications for bone healing using cultured periosteal cells transduced retrovirally with the BMP-7 gene. Annals of Plastic Surgery, 42, 488-495. doi:10.1097/00000637-199905000-00005

[81] Franceschi, R.T., Wang, D., Krebsbach, P.H. and Rutherford, R.B. (2000) Gene therapy for bone formation: In vitro and in vivo osteogenic activity of an adenovirus expressing BMP7. Journal of Cellular Biochemistry, 78, 476-486.

doi:10.1002/1097-4644(20000901)78:3<476::AID-JCB1 2>3.0.CO;2-5

[82] Gazit, D., Turgeman, G., Kelley, P., Wang, E., Jalenak, M., Zilberman, Y. and Moutsatsos, I. (1990) Engineered pluripotent mesenchymal cells integrate and differentiate in regenerating bone: A novel cell-mediated gene therapy. The Journal of Gene Medicine, 1, 121-133. doi:10.1002/(SICI)1521-2254(199903/04)1:2<121::AIDJGM26>3.0.CO;2-J

[83] Krebsbach, P.H., Gu, K., Franceschi, R.T. and Rutherford, R.B. (2000) Gene therapy-directed osteogenesis: BMP-7transduced human fibroblasts form bone in vivo. Human Gene Therapy, 11, 1201-1210. doi:10.1089/10430340050015248

[84] Lee, J.Y., Musgrave, D., Pelinkovic, D., Fukushima, K., Cummins, J., Usas, A., Robbins, P., Fu, F.H. and Huard, J. (2001) Effect of bone morphogenetic protein-2-expressing muscle-derived cells on healing of critical-sized bone defects in mice. The Journal of Bone and Joint Surgery. American Volume, 83-A, 1032-1039.

[85] Lieberman, J.R., Le, L.Q., Wu, L., Finerman, G.A., Berk, A., Witte, O.N. and Stevenson, S. (1998) Regional gene therapy with a BMP-2-producing murine stromal cell line induces heterotopic and orthotopic bone formation in rodents. Journal of Orthopaedic Research, 16, 330-339. doi:10.1002/jor.1100160309

[86] Lou, J., Xu, F., Merkel, K. and Manske, P. (1999) Gene therapy: Adenovirus-mediated human bone morphogenetic protein-2 gene transfer induces mesenchymal progenitor cell proliferation and differentiation in vitro and bone formation in vivo. Journal of Orthopaedic Research, 17, 43-50. doi:10.1002/jor.1100170108

[87] Mason, J.M., Grande, D.A., Barcia, M., Grant, R., Pergolizzi, R.G. and Breitbart, A.S. (1998) Expression of human bone morphogenic protein 7 in primary rabbit periosteal cells: Potential utility in gene therapy for osteochondral repair. Gene Therapy, 5, 1098-1104. doi:10.1038/sj.gt.3300703

[88] Musgrave, D.S., Bosch, P., Ghivizzani, S., Robbins, P.D., Evans, C.H. and Huard, J. (1999) Adenovirus-mediated direct gene therapy with bone morphogenetic protein-2 produces bone. Bone, 24, 541-547. doi:10.1016/S8756-3282(99)00086-1

[89] Okubo, Y., Bessho, K., Fujimura, K., Iizuka, T. and Miyatake, S.I. (2000) Osteoinduction by bone morphogenetic protein-2 via adenoviral vector under transient immunosuppression. Biochemical and Biophysical Research Communications, 267, 382-387. doi:10.1006/bbrc.1999.1975

[90] Oyama, M., Tatlock, A., Fukuta, S., Kavalkovich, K.,
Nishimura, K., Johnstone, B., Robbins, P.D., Evans, C.H. and Niyibizi, C. (1999) Retrovirally transduced bone marrow stromal cells isolated from a mouse model of human osteogenesis imperfecta (oim) persist in bone and retain the ability to form cartilage and bone after extended passaging. Gene Therapy, 6, 321-329. doi:10.1038/sj.gt.3300839

[91] Riew, K.D., Wright, N.M., Cheng, S., Avioli, L.V. and Lou, J. (1998) Induction of bone formation using a recombinant adenoviral vector carrying the human BMP-2 gene in a rabbit spinal fusion model. Calcified Tissue International, 63, 357-360. doi:10.1007/s002239900540

[92] Ripamonti, U., Ramoshebi, L.N., Matsaba, T., Tasker, J., Crooks, J. and Teare, J. (2001) Bone induction by BMPs/OPs and related family members in primates. The Journal of Bone and Joint Surgery. American Volume, 83-A, S116-S127.

[93] Sandhu, H.S., Khan, S.N., Suh, D.Y. and Boden, S.D. (2001) Demineralized bone matrix, bone morphogenetic proteins, and animal models of spine fusion: An overview. European Spine Journal, 10, S122-S131. doi:10.1007/s005860100303

[94] Varady, P., Li, J.Z., Cunningham, M., Beres, E.J., Das, S., Engh, J., Alden, T.D., Pittman, D.D., Kerns, K.M., Kallmes, D.F. and Helm, G.A. (2001) Morphologic analysis of BMP-9 gene therapy-induced osteogenesis. Human Gene Therapy, 12, 697-710. doi:10.1089/104303401300057423

[95] Whang, K., Tsai, D.C., Nam, E.K., Aitken, M., Sprague, S.M., Patel, P.K. and Healy, K.E. (1998) Ectopic bone formation via rhBMP-2 delivery from porous bioabsorbable polymer scaffolds. Journal of Biomedical Materials Research, 42, 491-499. doi:10.1002/(SICI)1097-4636(19981215)42:4<491::AIDJBM3>3.0.CO;2-F

[96] He, T.C. (2005) Distinct osteogenic activity of BMPs and their orthopaedic applications. Journal of Musculoskeletal \& Neuronal Interactions, 5, 363-366.

[97] Lian, J.B., Stein, G.S., Javed, A., van Wijnen, A.J., Stein, J.L., Montecino, M., Hassan, M.Q., Gaur, T., Lengner, C.J. and Young, D.W. (2006) Networks and hubs for the transcriptional control of osteoblastogenesis. Reviews in Endocrine and Metabolic Disorders, 7, 1-16. doi:10.1007/s11154-006-9001-5

[98] Yamaguchi, A., Komori, T. and Suda, T. (2000) Regulation of osteoblast differentiation mediated by bone morphogenetic proteins, hedgehogs, and Cbfa1. Endocrine Reviews, 21, 393-411. doi:10.1210/er.21.4.393

[99] Cheng, S.L., Lou, J., Wright, N.M., Lai, C.F., Avioli, L.V. and Riew, K.D. (2001) In vitro and in vivo induction of bone formation using a recombinant adenoviral vector carrying the human BMP-2 gene. Calcified Tissue International, 68, 87-94. doi:10.1007/BF02678146

[100] Partridge, K., Yang, X., Clarke, N.M., Okubo, Y., Bessho, K., Sebald, W., Howdle, S.M., Shakesheff, K.M. and Oreffo, R.O. (2002) Adenoviral BMP-2 gene transfer in mesenchymal stem cells: In vitro and in vivo bone formation on biodegradable polymer scaffolds. Biochemical and Biophysical Research Communications, 292, 144- 
152. doi:10.1006/bbrc. 2002.6623

[101] Yang, M., Ma, Q.J., Dang, G.T., Ma, K., Chen, P. and Zhou, C.Y. (2005) In vitro and in vivo induction of bone formation based on ex vivo gene therapy using rat adipose-derived adult stem cells expressing BMP-7. Cytotherapy, 7, 273-281. doi:10.1080/14653240510027244

[102] Varady, P., Li, J.Z., Alden, T.D., Kallmes, D.F., Williams, M.B. and Helm, G.A. (2002) CT and radionuclide study of BMP-2 gene therapy-induced bone formation. Academic Radiology, 9, 632-637. doi:10.1016/S1076-6332(03)80307-0

[103] Cook, S.D., Baffes, G.C., Wolfe, M.W., Sampath, T.K. and Rueger, D.C. (1994) Recombinant human bone morphogenetic protein-7 induces healing in a canine long-bone segmental defect model. Clinical Orthopaedics and Related Research, 301, 302-312.

[104] Gerhart, T.N., Kirker-Head, C.A., Kriz, M.J., Holtrop, M.E., Hennig, G.E., Hipp, J., Schelling, S.H. and Wang, E. (1993) Healing segmental femoral defects in sheep using recombinant human bone morphogenetic protein. Clinical Orthopaedics and Related Research, 293, 317326.

[105] Katagiri, T., Yamaguchi, A., Ikeda, T., Yoshiki, S., Wozney, J.M., Rosen, V., Wang, E.A., Tanaka, H., Omura, S. and Suda, T. (1990) The non-osteogenic mouse pluripotent cell line, C3H10T1/2, is induced to differentiate into osteoblastic cells by recombinant human bone morphogenetic protein-2. Biochemical and Biophysical Research Communications, 172, 295-299. doi:10.1016/S0006-291X(05)80208-6

[106] Valentin-Opran, A., Wozney, J., Csimma, C., Lilly, L. and Riedel, G.E. (2002) Clinical evaluation of recombinant human bone morphogenetic protein-2. Clinical Orthopaedics and Related Research, 395, 110-120. doi:10.1097/00003086-200202000-00011

[107] Yamaguchi, A., Katagiri, T., Ikeda, T., Wozney, J.M., Rosen, V., Wang, E.A., Kahn, A.J., Suda, T. and Yoshiki, S. (1991) Recombinant human bone morphogenetic protein-2 stimulates osteoblastic maturation and inhibits myogenic differentiation in vitro. Journal of Cell Biology, 113, 681-687. doi:10.1083/jcb.113.3.681

[108] Yasko, A.W., Lane, J.M., Fellinger, E.J., Rosen, V., Wozney, J.M. and Wang, E.A. (1992) The healing of segmental bone defects, induced by recombinant human bone morphogenetic protein (rhBMP-2). A radiographic, histological, and biomechanical study in rats. The Journal of Bone and Joint Surgery. American Volume, 74, 659670.

[109] Boden, S.D., Zdeblick, T.A., Sandhu, H.S. and Heim, S.E. (2000) The use of rhBMP-2 in interbody fusion cages. Definitive evidence of osteoinduction in humans: A preliminary report. Spine, 25, 376-381.

[110] Govender, S., Csimma, C., Genant, H.K., Valentin-Opran, A., Amit, Y., Arbel, R., Aro, H., Atar, D., Bishay, M., Borner, M.G., Chiron, P., Choong, P., Cinats, J., Courtenay, B., Feibel, R., Geulette, B., Gravel, C., Haas, N., Raschke, M., Hammacher, E., van der Velde, D., Hardy, P., Holt, M., Josten, C., Ketterl, R.L., Lindeque, B., Lob, G., Mathevon, H., McCoy, G., Marsh, D., Miller, R.,
Munting, E., Oevre, S., Nordsletten, L., Patel, A., Pohl, A., Rennie, W., Reynders, P., Rommens, P.M., Rondia, J., Rossouw, W.C., Daneel, P.J., Ruff, S., Ruter, A., Santavirta, S., Schildhauer, T.A., Gekle, C., Schnettler, R., Segal, D., Seiler, H., Snowdowne, R.B., Stapert, J., Taglang, G., Verdonk, R., Vogels, L., Weckbach, A., Wentzensen, A. and Wisniewski, T. (2002) Recombinant human bone morphogenetic protein-2 for treatment of open tibial fractures: A prospective, controlled, randomized study of four hundred and fifty patients. The Journal of Bone and Joint Surgery. American Volume, 84-A, 2123-2134.

[111] Bostrom, M.P. and Camacho, N.P. (1998) Potential role of bone morphogenetic proteins in fracture healing. Clinical Orthopaedics and Related Research, 355S, S274S282.

[112] Heckman, J.D., Boyan, B.D., Aufdemorte, T.B. and Abbott, J.T. (1991) The use of bone morphogenetic protein in the treatment of non-union in a canine model. The Journal of Bone and Joint Surgery. American Volume, 73, 750-764.

[113] Helm, G.A., Alden, T.D., Beres, E.J., Hudson, S.B., Das, S., Engh, J.A., Pittman, D.D., Kerns, K.M. and Kallmes, D.F. (2000) Use of bone morphogenetic protein-9 gene therapy to induce spinal arthrodesis in the rodent. Journal of Neurosurgery, 92, 191-196.

[114] Lee, A.R., Wilkins, A.C., Leather, C. and Brenton, A.G. (1994) Translational energy spectra for single-electron capture by $\mathrm{O}^{2+}$ in He, Ne, and Ar. Physical Review A, 50, 1149-1154. doi:10.1103/PhysRevA.50.1149

[115] Luo, J., Sun, M.H., Kang, Q., Peng, Y., Jiang, W., Luu, H.H., Luo, Q., Park, J.Y., Li, Y., Haydon, R.C. and He, T.C. (2005) Gene therapy for bone regeneration. Current Gene Therapy, 5, 167-179. doi:10.2174/1566523053544218

[116] Tang, N., Song, W.X., Luo, J., Haydon, R.C. and He, T.C. (2008) Osteosarcoma development and stem cell differrentiation. Clinical Orthopaedics and Related Research, 466, 2114-2130. doi:10.1007/s11999-008-0335-Z

[117] Wagner, E.R., He, B.C., Chen, L., Zuo, G.W., Zhang, W., Shi, Q., Luo, Q., Luo, X., Liu, B., Luo, J., Rastegar, F., He, C.J., Hu, Y., Boody, B., Luu, H.H., He, T.C., Deng, Z.L. and Haydon, R.C. (2010) Therapeutic implications of PPARgamma in human osteosarcoma. PPAR Research, 2010, 956427.

[118] Bertone, A.L., Pittman, D.D., Bouxsein, M.L., Li, J., Clancy, B. and Seeherman, H.J. (2004) Adenoviral-mediated transfer of human BMP-6 gene accelerates healing in a rabbit ulnar osteotomy model. Journal of Orthopaedic Research, 22, 1261-1270. doi:10.1016/j.orthres.2004.03.014

[119] Boden, S.D., Hair, G., Titus, L., Racine, M., McCuaig, K., Wozney, J.M. and Nanes, M.S. (1997) Glucocorticoidinduced differentiation of fetal rat calvarial osteoblasts is mediated by bone morphogenetic protein-6. Endocrinology, 138, 2820-2828. doi:10.1210/en.138.7.2820

[120] Boskey, A.L., Paschalis, E.P., Binderman, I. and Doty, S.B. (2002) BMP-6 accelerates both chondrogenesis and mineral maturation in differentiating chick limb-bud 
mesenchymal cell cultures. Journal of Cellular Biochemistry, 84, 509-519. doi:10.1002/jcb.10032

[121] Ebisawa, T., Tada, K., Kitajima, I., Tojo, K., Sampath, T.K., Kawabata, M., Miyazono, K. and Imamura, T. (1999) Characterization of bone morphogenetic protein-6 signaling pathways in osteoblast differentiation. Journal of Cell Science, 112, 3519-3527.

[122] Friedman, M.S., Long, M.W. and Hankenson, K.D. (2006) Osteogenic differentiation of human mesenchymal stem cells is regulated by bone morphogenetic protein-6. Journal of Cellular Biochemistry, 98, 538-554. doi:10.1002/jcb.20719

[123] Hughes, F.J., Collyer, J., Stanfield, M. and Goodman, S.A. (1995) The effects of bone morphogenetic protein-2, -4 , and -6 on differentiation of rat osteoblast cells in vitro. Endocrinology, 136, 2671-2677. doi:10.1210/en.136.6.2671

[124] Jane Jr., J.A., Dunford, B.A., Kron, A., Pittman, D.D., Sasaki, T., Li, J.Z., Li, H., Alden, T.D., Dayoub, H., Hankins, G.R., Kallmes, D.F. and Helm, G.A. (2002) Ectopic osteogenesis using adenoviral bone morphogenetic protein (BMP)-4 and BMP-6 gene transfer. Molecular Therapy, 6, 464-470. doi:10.1006/mthe.2002.0691

[125] Valdes, M., Moore, D.C., Palumbo, M., Lucas, P.R., Robertson, A., Appel, J., Ehrlich, M.G. and Keeping, H.S. (2007) rhBMP-6 stimulated osteoprogenitor cells enhance posterolateral spinal fusion in the New Zealand white rabbit. The Spine Journal, 7, 318-325. doi:10.1016/j.spinee.2006.02.005

[126] Visser, R., Arrabal, P.M., Santos-Ruiz, L., Becerra, J. and Cifuentes, M. (2012) Basic fibroblast growth factor enhances the osteogenic differentiation induced by bone morphogenetic protein-6 in vitro and in vivo. Cytokine, 58, 27-33. doi:10.1016/j.cyto.2011.12.020

[127] Yamaguchi, A., Ishizuya, T., Kintou, N., Wada, Y., Katagiri, T., Wozney, J.M., Rosen, V. and Yoshiki, S. (1996) Effects of BMP-2, BMP-4, and BMP-6 on osteoblastic differentiation of bone marrow-derived stromal cell lines, ST2 and MC3T3-G2/PA6. Biochemical and Biophysical Research Communications, 220, 366-371. doi:10.1006/bbrc.1996.0411

[128] Zachos, T.A., Shields, K.M. and Bertone, A.L. (2006) Gene-mediated osteogenic differentiation of stem cells by bone morphogenetic proteins-2 or -6. Journal of Orthopaedic Research, 24, 1279-1291. doi:10.1002/jor.20068

[129] Aslan, H., Zilberman, Y., Arbeli, V., Sheyn, D., Matan, Y., Liebergall, M., Li, J.Z., Helm, G.A., Gazit, D. and Gazit, Z. (2006) Nucleofection-based ex vivo nonviral gene delivery to human stem cells as a platform for tissue regeneration. Tissue Engineering, 12, 877-889. doi:10.1089/ten.2006.12.877

[130] Santos, J.L., Pandita, D., Rodrigues, J., Pego, A.P., Granja, P.L. and Tomas, H. (2011) Non-viral gene delivery to mesenchymal stem cells: Methods, strategies and application in bone tissue engineering and regeneration. Current Gene Therapy, 11, 46-57. doi:10.2174/156652311794520102

[131] Sheyn, D., Kimelman-Bleich, N., Pelled, G., Zilberman,
Y., Gazit, D. and Gazit, Z. (2008) Ultrasound-based nonviral gene delivery induces bone formation in vivo. Gene Therapy, 15, 257-266. doi:10.1038/sj.gt.3303070

[132] Bergeron, E., Senta, H., Mailloux, A., Park, H., Lord, E. and Faucheux, N. (2009) Murine preosteoblast differenttiation induced by a peptide derived from bone morphogenetic proteins-9. Tissue Engineering Part A, 15, 33413349. doi:10.1089/ten.tea.2009.0189

[133] Lee, J.Y., Peng, H., Usas, A., Musgrave, D., Cummins, J., Pelinkovic, D., Jankowski, R., Ziran, B., Robbins, P. and Huard, J. (2002) Enhancement of bone healing based on ex vivo gene therapy using human muscle-derived cells expressing bone morphogenetic protein 2. Human Gene Therapy, 13, 1201-1211. doi:10.1089/104303402320138989

[134] Dumont, R.J., Dayoub, H., Li, J.Z., Dumont, A.S., Kallmes, D.F., Hankins, G.R. and Helm, G.A. (2002) Ex vivo bone morphogenetic protein-9 gene therapy using human mesenchymal stem cells induces spinal fusion in rodents. Neurosurgery, 51, 1239-1244.

[135] Kimelman-Bleich, N., Pelled, G., Zilberman, Y., Kallai, I., Mizrahi, O., Tawackoli, W., Gazit, Z. and Gazit, D. (2011) Targeted gene-and-host progenitor cell therapy for nonunion bone fracture repair. Molecular Therapy, 19, 53-59. doi:10.1038/mt.2010.190

[136] Li, X., Chen. L., Ke, Z.-Y., Yin, L.-J. and Deng, Z.-L. (2012) BMP9-induced osteogenic differentiation and bone formation of muscle-derived stem cells. Journal of Biomedicine and Biotechnology, 2012, 1.

[137] Brown, M.A., Zhao, Q., Baker, K.A., Naik, C., Chen, C., Pukac, L., Singh, M., Tsareva, T., Parice, Y., Mahoney, A., Roschke, V., Sanyal, I. and Choe, S. (2005) Crystal structure of BMP-9 and functional interactions with pro-region and receptors. The Journal of Biological Chemistry, 280, 25111-25118. doi:10.1074/jbc.M503328200

[138] Canalis, E., Economides, A.N. and Gazzerro, E. (2003) Bone morphogenetic proteins, their antagonists, and the skeleton. Endocrine Reviews, 24, 218-235. doi:10.1210/er.2002-0023

[139] Hill, J.J., Qiu, Y., Hewick, R.M. and Wolfman, N.M. (2003) Regulation of myostatin in vivo by growth and differentiation factor-associated serum protein-1: A novel protein with protease inhibitor and follistatin domains. Molecular Endocrinology, 17, 1144-1154. doi:10.1210/me.2002-0366

[140] Li, J.Z., Li, H., Sasaki, T., Holman, D., Beres, B., Dumont, R.J., Pittman, D.D., Hankins, G.R. and Helm, G.A. (2003) Osteogenic potential of five different recombinant human bone morphogenetic protein adenoviral vectors in the rat. Gene Therapy, 10, 1735-1743. doi:10.1038/sj.gt.3302075

[141] Sieber, C., Kopf, J., Hiepen, C. and Knaus, P. (2009) Recent advances in BMP receptor signaling. Cytokine \& Growth Factor Reviews, 20, 343-355. doi:10.1016/j.cytogfr.2009.10.007

[142] Zhou, L., An, N., Jiang, W., Haydon, R., Cheng, H., Zhou, Q., Breyer, B., Feng, T. and He, T.C. (2002) Fluorescence-based functional assay for Wnt/beta-catenin sig- 
naling activity. Biotechniques, 33, 1126-1128, 1130, 1132 passim.

[143] Massague, J. (1998) TGF-beta signal transduction. Annual Review of Biochemistry, 67, 753-791. doi:10.1146/annurev.biochem.67.1.753

[144] Yamashita, H., Ten Dijke, P., Heldin, C.H. and Miyazono, K. (1996) Bone morphogenetic protein receptors. Bone, 19, 569-574. doi:10.1016/S8756-3282(96)00259-1

[145] Yamashita, H. and Miyazono, K. (1999) Bone morphogenetic protein (BMP) receptors and signal transduction. Nihon Rinsho, 57, 220-226.

[146] Scharpfenecker, M., van Dinther, M., Liu, Z., van Bezooijen, R.L., Zhao, Q., Pukac, L., Lowik, C.W. and ten Dijke, P. (2007) BMP-9 signals via ALK1 and inhibits bFGF-induced endothelial cell proliferation and VEGFstimulated angiogenesis. Journal of Cell Science, 120, 964-972. doi:10.1242/jcs.002949

[147] Shao, E.S., Lin, L., Yao, Y. and Bostrom, K.I. (2009) Expression of vascular endothelial growth factor is coordinately regulated by the activin-like kinase receptors 1 and 5 in endothelial cells. Blood, 114, 2197-2206. doi:10.1182/blood-2009-01-199166

[148] Upton, P.D., Davies, R.J., Trembath, R.C. and Morrell, N.W. (2009) Bone morphogenetic protein (BMP) and activin type II receptors balance BMP9 signals mediated by activin receptor-like kinase-1 in human pulmonary artery endothelial cells. The Journal of Biological Chemistry, 284, 15794-15804. doi:10.1074/jbc.M109.002881

[149] Massague, J., Seoane, J. and Wotton, D. (2005) Smad transcription factors. Genes \& Development, 19, 27832810. doi:10.1101/gad.1350705

[150] Nohe, A., Keating, E., Knaus, P. and Petersen, N.O. (2004) Signal transduction of bone morphogenetic protein receptors. Cellular Signalling, 16, 291-299. doi:10.1016/j.cellsig.2003.08.011

[151] Heldin, C.H., Miyazono, K. and ten Dijke, P. (1997) TGF-beta signalling from cell membrane to nucleus through SMAD proteins. Nature, 390, 465-471.

[152] Wrana, J.L. (2000) Regulation of Smad activity. Cell, 100, 189-192. doi:10.1016/S0092-8674(00)81556-1

[153] Derynck, R., Zhang, Y. and Feng, X.H. (1998) Smads: transcriptional activators of TGF-beta responses. Cell, 95, 737-740. doi:10.1016/S0092-8674(00)81696-7

[154] Itoh, S., Itoh, F., Goumans, M.J. and Ten Dijke, P. (2000) Signaling of transforming growth factor-beta family members through Smad proteins. European Journal of Biochemistry, 267, 6954-6967. doi:10.1046/j.1432-1327.2000.01828.x

[155] Miyazono, K., ten Dijke, P. and Heldin, C.H. (2000) TGF-beta signaling by Smad proteins. Advances in Immunology, 75, 115-157. doi:10.1016/S0065-2776(00)75003-6

[156] Ten Dijke, P., Goumans, M.J., Itoh, F. and Itoh, S. (2002) Regulation of cell proliferation by Smad proteins. Journal of Cellular Physiology, 191, 1-16. doi:10.1002/jcp.10066

[157] Miyazono, K., Maeda, S. and Imamura, T. (2005) BMP receptor signaling: Transcriptional targets, regulation of signals, and signaling cross-talk. Cytokine \& Growth Factor Reviews, 16, 251-263. doi:10.1016/j.cytogfr.2005.01.009

[158] Xu, D.J., Zhao, Y.-Z., Wang, J., He, J.W., Weng, Y.G. and Luo, J.Y. (2011) Smads, p38 and ERK1/2 are involved in BMP9-induced osteogenic differentiation of C3H10T1/2 mesenchymal stem cells. BMB Reports, 45, 247-252.

[159] Kreider, B.L., Benezra, R., Rovera, G. and Kadesch, T. (1992) Inhibition of myeloid differentiation by the helixloop-helix protein Id. Science, 255, 1700-1702. doi:10.1126/science.1372755

[160] Norton, J.D. (2000) ID helix-loop-helix proteins in cell growth, differentiation and tumorigenesis. Journal of Cell Science, 113, 3897-3905.

[161] Ruzinova, M.B. and Benezra, R. (2003) Id proteins in development, cell cycle and cancer. Trends in Cell Biology, 13, 410-418. doi:10.1016/S0962-8924(03)00147-8

[162] Blom, I.E., Goldschmeding, R. and Leask, A. (2002) Gene regulation of connective tissue growth factor: New targets for antifibrotic therapy? Matrix Biology, 21, 473482. doi:10.1016/S0945-053X(02)00055-0

[163] Brigstock, D.R. (2003) The CCN family: A new stimulus package. Journal of Endocrinology, 178, 169-175. doi:10.1677/joe.0.1780169

[164] Brigstock, D.R., Goldschmeding, R., Katsube, K.I., Lam, S.C., Lau, L.F., Lyons, K., Naus, C., Perbal, B., Riser, B., Takigawa, M. and Yeger, H. (2003) Proposal for a unified CCN nomenclature. Molecular Pathology, 56, $127-$ 128. doi:10.1136/mp.56.2.127

[165] Lau, L.F. and Lam, S.C. (1999) The CCN family of angiogenic regulators: The integrin connection. Experimental Cell Research, 248, 44-57. doi:10.1006/excr.1999.4456

[166] Moussad, E.E. and Brigstock, D.R. (2000) Connective tissue growth factor: What's in a name? Molecular Genetics and Metabolism, 71, 276-292. doi:10.1006/mgme.2000.3059

[167] Planque, N. and Perbal, B. (2003) A structural approach to the role of CCN (CYR61/CTGF/NOV) proteins in tumourigenesis. Cancer Cell International, 3, 15. doi:10.1186/1475-2867-3-15

[168] Ivkovic, S., Yoon, B.S., Popoff, S.N., Safadi, F.F., Libuda, D.E., Stephenson, R.C., Daluiski, A. and Lyons, K.M. (2003) Connective tissue growth factor coordinates chondrogenesis and angiogenesis during skeletal development. Development and Disease, 130, 2779-2791. doi:10.1242/dev.00505

[169] Sharff, K.A., Song, W.X., Luo, X., Tang, N., Luo, J., Chen, J., Bi, Y., He, B.C., Huang, J., Li, X., Jiang, W., Zhu, G.H., Su, Y., He, Y., Shen, J., Wang, Y., Chen, L., Zuo, G.W., Liu, B., Pan, X., Reid, R.R., Luu, H.H., Haydon, R.C. and He, T.C. (2009) Hey1 basic helix-loop-helix protein plays an important role in mediating BMP9induced osteogenic differentiation of mesenchymal progenitor cells. The Journal of Biological Chemistry, 284, 649-659. doi:10.1074/jbc.M806389200 
[170] Massague, J. and Chen, Y.G. (2000) Controlling TGFbeta signaling. Genes \& Development, 14, 627-644.

[171] Massague, J. and Wotton, D. (2000) Transcriptional control by the TGF-beta/Smad signaling system. The EMBO Journal, 19, 1745-1754. doi:10.1093/emboj/19.8.1745

[172] Siegel, P.M. and Massague, J. (2003) Cytostatic and apoptotic actions of TGF-beta in homeostasis and cancer. Nature Reviews. Cancer, 3, 807-821.

[173] Siegel, P.M., Shu, W., Cardiff, R.D., Muller, W.J. and Massague, J. (2003) Transforming growth factor beta signaling impairs Neu-induced mammary tumorigenesis while promoting pulmonary metastasis. Proceedings of the National Academy of Sciences of the United States of America, 100, 8430-8435. doi:10.1073/pnas.0932636100

[174] Alliston, T., Choy, L., Ducy, P., Karsenty, G. and Derynck, R. (2001) TGF-beta-induced repression of CBFA1 by Smad3 decreases cbfa1 and osteocalcin expression and inhibits osteoblast differentiation. The EMBO Journal, 20, 2254-2272. doi:10.1093/emboj/20.9.2254

[175] Li, R.D., Deng, Z.L., Hu, N., Liang, X., Liu, B., Luo, J., Chen, L., Yin, L., Luo, X., Shui, W., He, T.C. and Huang, W. (2012) Biphasic effects of TGFbeta1 on BMP9-induced osteogenic differentiation of mesenchymal stem cells. BMB Reports, 45, 509-514.

[176] Maeda, S., Hayashi, M., Komiya, S., Imamura, T. and Miyazono, K. (2004) Endogenous TGF-beta signaling suppresses maturation of osteoblastic mesenchymal cells. The EMBO Journal, 23, 552-563. doi:10.1038/sj.emboj.7600067

[177] Huang, E., Zhu, G., Jiang, W., Yang, K., Gao, Y., Luo, Q., Gao, J.L., Kim, S.H., Liu, X., Li, M., Shi, Q., Hu, N., Wang, L., Liu, H., Cui, J., Zhang, W., Li, R., Chen, X., Kong, Y.H., Zhang, J., Wang, J., Shen, J., Bi, Y., Statz, J., He, B.C., Luo, J., Wang, H., Xiong, F., Luu, H.H., Haydon, R.C., Yang, L. and He, T.C. (2012) Growth hormone synergizes with BMP9 in osteogenic differentiation by activating the JAK/STAT/IGF1 pathway in murine multilineage cells. Journal of Bone and Mineral Research, 27, 1566-1575. doi:10.1002/jbmr.1622

[178] Blair, J.C. and Savage, M.O. (2002) The GH-IGF-I axis in children with idiopathic short stature. Trends in Endocrinology \& Metabolism, 13, 325-330. doi:10.1016/S1043-2760(02)00631-8

[179] Brooks, A.J. and Waters, M.J. (2010) The growth hormone receptor: Mechanism of activation and clinical implications. Nature Reviews. Endocrinology, 6, 515-525.

[180] Hull, K.L. and Harvey, S. (2000) Growth hormone: Roles in male reproduction. Endocrine, 13, 243-250. doi:10.1385/ENDO:13:3:243

[181] Hull, K.L. and Harvey, S. (2000) Growth hormone: A reproductive endocrine-paracrine regulator? Reviews of Reproduction, 5, 175-182. doi:10.1530/ror.0.0050175

[182] Park, P. and Cohen, P. (2005) Insulin-like growth factor I (IGF-I) measurements in growth hormone (GH) therapy of idiopathic short stature (ISS). Growth Hormone \& IGF Research, 15, S13-S20.

[183] Tanaka, H. (1998) Growth hormone and bone diseases.
Endocrine Journal, 45, S47-S52. doi:10.1507/endocrj.45.Suppl S47

[184] Thomas, M.J. (1998) The molecular basis of growth hormone action. Growth Hormone \& IGF Research, 8, 3-11. doi:10.1016/S1096-6374(98)80316-X

[185] Randhawa, R. and Cohen, P. (2005) The role of the insulin-like growth factor system in prenatal growth. Molecular Genetics and Metabolism, 86, 84-90. doi:10.1016/j.ymgme.2005.07.028

[186] O’Dell, S.D. and Day, I.N. (1998) Insulin-like growth factor II (IGF-II). The International Journal of Biochemistry \& Cell Biology, 30, 767-771. doi:10.1016/S1357-2725(98)00048-X

[187] Bergwitz, C., Wendlandt, T., Kispert, A. and Brabant, G. (2001) Wnts differentially regulate colony growth and differentiation of chondrogenic rat calvaria cells. Biochimica et Biophysica Acta (BBA)-Molecular Cell Research, 1538, 129-140. doi:10.1016/S0167-4889(00)00123-3

[188] Cadigan, K.M. and Nusse, R. (1997) Wnt signaling: A common theme in animal development. Genes \& Development, 11, 3286-3305. doi:10.1101/gad.11.24.3286

[189] Fischer, L., Boland, G. and Tuan, R.S. (2002) Wnt signaling during BMP-2 stimulation of mesenchymal chondrogenesis. Journal of Cellular Physiology, 84, 816-831. doi:10.1002/jcb.10091

[190] Glass 2nd., D.A. and Karsenty, G. (2006) Molecular bases of the regulation of bone remodeling by the canonical Wnt signaling pathway. Current Topics in Developmental Biology, 73, 43-84. doi:10.1016/S0070-2153(05)73002-7

[191] Glass 2nd., D.A. and Karsenty, G. (2007) In vivo analysis of Wnt signaling in bone. Endocrinology, 148, 2630-2634. doi:10.1210/en.2006-1372

[192] Karsenty, G. and Wagner, E.F. (2002) Reaching a genetic and molecular understanding of skeletal development. Developmental Cell, 2, 389-406. doi:10.1016/S1534-5807(02)00157-0

[193] Wang, J. and Wynshaw-Boris, A. (2004) The canonical Wnt pathway in early mammalian embryogenesis and stem cell maintenance/differentiation. Current Opinion in Genetics \& Development, 14, 533-539. doi:10.1016/j.gde.2004.07.013

[194] Tang, N., Song, W.X., Luo, J., Luo, X., Chen, J., Sharff, K.A., Bi, Y., He, B.C., Huang, J.Y., Zhu, G.H., Su, Y.X., Jiang, W., Tang, M., He, Y., Wang, Y., Chen, L., Zuo, G.W., Shen, J., Pan, X., Reid, R.R., Luu, H.H., Haydon, R.C. and He, T.C. (2009) BMP-9-induced osteogenic differentiation of mesenchymal progenitors requires functional canonical Wnt/beta-catenin signalling. Journal of Cellular and Molecular Medicine, 13, 2448-2464. doi:10.1111/j.1582-4934.2008.00569.X

[195] Gong, Y., Slee, R.B., Fukai, N., Rawadi, G., RomanRoman, S., Reginato, A.M., Wang, H., Cundy, T., Glorieux, F.H., Lev, D., Zacharin, M., Oexle, K., Marcelino, J., Suwairi, W., Heeger, S., Sabatakos, G., Apte, S., Adkins, W.N., Allgrove, J., Arslan-Kirchner, M., Batch, J.A., Beighton, P., Black, G.C., Boles, R.G., Boon, L.M., Bor- 
rone, C., Brunner, H.G., Carle, G.F., Dallapiccola, B., De Paepe, A., Floege, B., Halfhide, M.L., Hall, B., Hennekam, R.C., Hirose, T., Jans, A., Juppner, H., Kim, C.A., Keppler-Noreuil, K., Kohlschuetter, A., LaCombe, D., Lambert, M., Lemyre, E., Letteboer, T., Peltonen, L., Ramesar, R.S., Romanengo, M., Somer, H., SteichenGersdorf, E., Steinmann, B., Sullivan, B., Superti-Furga, A., Swoboda, W., van den Boogaard, M.J., Van Hul, W., Vikkula, M., Votruba, M., Zabel, B., Garcia, T., Baron, R., Olsen, B.R. and Warman, M.L. (2001) LDL receptorrelated protein 5 (LRP5) affects bone accrual and eye development. Cell, 107, 513-523. doi:10.1016/S0092-8674(01)00571-2

[196] Celil, A.B. and Campbell, P.G. (2005) BMP-2 and insulin-like growth factor-I mediate osterix (Osx) expression in human mesenchymal stem cells via the MAPK and protein kinase D signaling pathways. The Journal of Biological Chemistry, 280, 31353-31359. doi:10.1074/jbc.M503845200

[197] Chang, S.F., Chang, T.K., Peng, H.H., Yeh, Y.T., Lee, D.Y., Yeh, C.R., Zhou, J., Cheng, C.K., Chang, C.A. and Chiu, J.J. (2009) BMP-4 induction of arrest and differenttiation of osteoblast-like cells via $\mathrm{p} 21^{\mathrm{CIP} 1}$ and $\mathrm{p} 27^{\mathrm{KIP} 1}$ regulation. Molecular Endocrinology, 23, 1827-1838. doi:10.1210/me.2009-0143

[198] Gallea, S., Lallemand, F., Atfi, A., Rawadi, G., Ramez, V., Spinella-Jaegle, S., Kawai, S., Faucheu, C., Huet, L., Baron, R. and Roman-Roman, S. (2001) Activation of mitogen-activated protein kinase cascades is involved in regulation of bone morphogenetic protein-2-induced osteoblast differentiation in pluripotent $\mathrm{C} 2 \mathrm{C} 12$ cells. Bone, 28, 491-498. doi:10.1016/S8756-3282(01)00415-X

[199] Noth, U., Tuli, R., Seghatoleslami, R., Howard, M., Shah, A., Hall, D.J., Hickok, N.J. and Tuan, R.S. (2003) Activation of p38 and Smads mediates BMP-2 effects on human trabecular bone-derived osteoblasts. Experimental Cell Research, 291, 201-211. doi:10.1016/S0014-4827(03)00386-0

[200] Miyazono, K., Kamiya, Y. and Morikawa, M. (2010) Bone morphogenetic protein receptors and signal transduction. The Journal of Biochemistry, 147, 35-51. doi:10.1093/jb/mvp148

[201] Verheyen, E.M. (2007) Opposing effects of Wnt and MAPK on BMP/Smad signal duration. Developmental Cell, 13, 755-756. doi:10.1016/j.devcel.2007.11.006

[202] Majmundar, A.J., Wong, W.J. and Simon, M.C. (2010) Hypoxia-inducible factors and the response to hypoxic stress. Molecular Cell, 40, 294-309. doi:10.1016/j.molcel.2010.09.022

[203] Giaginis, C., Tsantili-Kakoulidou, A. and Theocharis, S. (2007) Peroxisome proliferator-activated receptors (PPARs) in the control of bone metabolism. Fundamental \& Clinical Pharmacology, 21, 231-244. doi:10.1111/j.1472-8206.2007.00486.x

[204] Muruganandan, S., Roman, A.A. and Sinal, C.J. (2009) Adipocyte differentiation of bone marrow-derived mesenchymal stem cells: Cross talk with the osteoblastogenic program. Cellular and Molecular Life Sciences, 66, 236253. doi:10.1007/s00018-008-8429-z
[205] Chawla, A., Repa, J.J., Evans, R.M. and Mangelsdorf, D.J. (2001) Nuclear receptors and lipid physiology: Opening the X-files. Science, 294, 1866-1870. doi:10.1126/science.294.5548.1866

[206] Mark, M., Ghyselinck, N.B. and Chambon, P. (2006) Function of retinoid nuclear receptors: Lessons from genetic and pharmacological dissections of the retinoic acid signaling pathway during mouse embryogenesis. Annual Review of Pharmacology and Toxicology, 46, 451-480. doi:10.1146/annurev.pharmtox.46.120604.141156

[207] Chen, L., Jiang, W., Huang, J., He, B.C., Zuo, G.W., Zhang, W., Luo, Q., Shi, Q., Zhang, B.Q., Wagner, E.R., Luo, J., Tang, M., Wietholt, C., Luo, X., Bi, Y., Su, Y., Liu, B., Kim, S.H., He, C.J., Hu, Y., Shen, J., Rastegar, F., Huang, E., Gao, Y., Gao, J.L., Zhou, J.Z., Reid, R.R., Luu, H.H., Haydon, R.C., He, T.C. and Deng, Z.L. (2010) Insulin-like growth factor 2 (IGF-2) potentiates BMP-9induced osteogenic differentiation and bone formation. Journal of Bone and Mineral Research, 25, 2447-2459. doi:10.1002/jbmr.133

[208] Zhao, Y., Song, T., Wang, W., Wang, J., He, J., Wu, N., Tang, M., He, B. and Luo, J. (2012) P38 and ERK1/2 MAPKs act in opposition to regulate BMP9-induced osteogenic differentiation of mesenchymal progenitor cells. PLoS One, 7, e43383. doi:10.1371/journal.pone.0043383

[209] Hu, N., Jiang, D., Huang, E., Liu X., Li, R.D., Liang, X., Stephanie, H. and Kim, X.C., Gao, J.-L., Zhang, H.Y. and Zhang, W.W. (2013) BMP9-regulated angiogenic signaling plays an important role in the osteogenic differentiation of mesenchymal progenitor cells. Journal of Cell Science, 126, 532-541.

[210] Zhang, W., Deng, Z.L., Chen, L., Zuo, G.W., Luo, Q., Shi, Q., Zhang, B.Q., Wagner, E.R., Rastegar, F., Kim, S.H., Jiang, W., Shen, J., Huang, E., Gao, Y., Gao, J.L., Zhou, J.Z., Luo, J., Huang, J., Luo, X., Bi, Y., Su, Y., Yang, K., Liu, H., Luu, H.H., Haydon, R.C., He, T.C. and He, B.C. (2010) Retinoic acids potentiate BMP9-induced osteogenic differentiation of mesenchymal progenitor cells. PLoS One, 5, e11917. doi:10.1371/journal.pone.0011917

[211] Castonguay, R., Werner, E.D., Matthews, R.G., Presman, E., Mulivor, A.W., Solban, N., Sako, D., Pearsall, R.S, Underwood, K.W., Seehra, J., Kumar, R. and Grinberg, A.V. (2011) Soluble endoglin specifically binds bone morphogenetic proteins 9 and 10 via its orphan domain, inhibits blood vessel formation, and suppresses tumor growth. The Journal of Biological Chemistry, 286 30034-30046. doi:10.1074/jbc.M111.260133

[212] Li, B., Yang, Y., Jiang, S., Ni, B., Chen, K. and Jiang, L. (2012) Adenovirus-mediated overexpression of BMP-9 inhibits human osteosarcoma cell growth and migration through downregulation of the PI3K/AKT pathway. Internation Journal of Oncology, 41, 1809-1819.

[213] Ye, L., Kynaston, H. and Jiang, W.G. (2008) Bone morphogenetic protein-9 induces apoptosis in prostate cancer cells, the role of prostate apoptosis response-4. Molecular Cancer Research, 6, 1594-1606. doi:10.1158/1541-7786.MCR-08-0171 
[214] van Meeteren, L.A., Thorikay, M., Bergqvist, S., Pardali, E., Stampino, C.G., Hu-Lowe, D., Goumans, M.J. and ten Dijke, P. (2012) Anti-human activin receptor-like kinase 1 (ALK1) antibody attenuates bone morphogenetic protein 9 (BMP9)-induced ALK1 signaling and interferes with endothelial cell sprouting. The Journal of Biological Chemistry, 287, 18551-18561. doi:10.1074/jbc.M111.338103

[215] Ricard, N., Ciais, D., Levet, S., Subileau, M., Mallet, C., Zimmers, T.A., Lee, S.J., Bidart, M., Feige, J.J. and Bailly, S. (2012) BMP9 and BMP10 are critical for postnatal retinal vascular remodeling. Blood, 119, 6162-6171. doi:10.1182/blood-2012-01-407593

[216] Suzuki, Y., Ohga, N., Morishita, Y., Hida, K., Miyazono, K. and Watabe, T. (2010) BMP-9 induces proliferation of multiple types of endothelial cells in vitro and in vivo. Journal of Cell Science, 123, 1684-1692. doi:10.1242/jcs.061556

[217] David, L., Mallet, C., Keramidas, M., Lamande, N., Gasc, J.M., Dupuis-Girod, S., Plauchu, H., Feige, J.J. and Bailly, S. (2008) Bone morphogenetic protein-9 is a circulating vascular quiescence factor. Circulation Research, 102, 914-922. doi:10.1161/CIRCRESAHA.107.165530

[218] Park, J.E., Shao, D., Upton, P.D., Desouza, P., Adcock, I.M., Davies, R.J., Morrell, N.W., Griffiths, M.J. and Wort, S.J. (2012) BMP-9 induced endothelial cell tubule formation and inhibition of migration involves Smad1 driven endothelin-1 production. PLoS One, 7, e30075. doi:10.1371/journal.pone.0030075

[219] Yao, Y., Jumabay, M., Ly, A., Radparvar, M., Wang, A.H., Abdmaulen, R. and Bostrom, K.I. (2012) Crossveinless 2 regulates bone morphogenetic protein 9 in human and mouse vascular endothelium. Blood, 119, 50375047. doi:10.1182/blood-2011-10-385906

[220] Lopez-Coviella, I., Follettie, M.T., Mellott, T.J., Kovacheva, V.P., Slack, B.E., Diesl, V., Berse, B., Thies, R.S. and Blusztajn, J.K. (2005) Bone morphogenetic protein 9 induces the transcriptome of basal forebrain cholinergic neurons. Proceedings of the National Academy of Sciences of the United States of America, 102, 6984-6989. doi:10.1073/pnas.0502097102

[221] Lopez-Coviella, I., Mellott, T.J., Schnitzler, A.C. and
Blusztajn, J.K. (2011) BMP9 protects septal neurons from axotomy-evoked loss of cholinergic phenotype. PLoS One, 6, e21166. doi:10.1371/journal.pone.0021166

[222] Schnitzler, A.C., Lopez-Coviella, I. and Blusztajn, J.K. (2008) Differential modulation of nerve growth factor receptor (p75) and cholinergic gene expression in purified p75-expressing and non-expressing basal forebrain neurons by BMP9. Brain Research, 1246, 19-28. doi:10.1016/j.brainres.2008.09.085

[223] Schnitzler, A.C., Mellott, T.J., Lopez-Coviella, I., Tallini, Y.N., Kotlikoff, M.I., Follettie, M.T. and Blusztajn, J.K. (2010) BMP9 (bone morphogenetic protein 9) induces NGF as an autocrine/paracrine cholinergic trophic factor in developing basal forebrain neurons. Journal of Neuroscience, 30, 8221-8228. doi:10.1523/JNEUROSCI.5611-09.2010

[224] Caperuto, L.C., Anhe, G.F., Cambiaghi, T.D., Akamine, E.H., do Carmo Buonfiglio, D., Cipolla-Neto, J., Curi, R. and Bordin, S. (2008) Modulation of bone morphogenetic protein-9 expression and processing by insulin, glucose, and glucocorticoids: Possible candidate for hepatic insulin-sensitizing substance. Endocrinology, 149, 6326-6335. doi:10.1210/en.2008-0655

[225] Sosa, I., Cvijanovic, O., Celic, T., Cuculic, D., CrncevicOrlic, Z., Vukelic, L., Zoricic Cvek, S., Dudaric, L., Bosnar, A. and Bobinac, D. (2011) Hepatoregenerative role of bone morphogenetic protein-9. Medical Science Monitor, 17, 33-35. doi:10.12659/MSM.882108

[226] Blunk, T., Sieminski, A.L., Appel, B., Croft, C., Courter, D.L., Chieh, J.J., Goepferich, A., Khurana, J.S. and Gooch, K.J. (2003) Bone morphogenetic protein 9: A potent modulator of cartilage development in vitro. Growth Factors, 21, 71-77. doi:10.1080/0897719031000148822

[227] Majumdar, M.K., Wang, E. and Morris, E.A. (2001) BMP-2 and BMP-9 promotes chondrogenic differentiation of human multipotential mesenchymal cells and overcomes the inhibitory effect of IL-1. Journal of Cellular Physiology, 189, 275-284. doi:10.1002/jcp.10025 